HEITOR AUGUSTO DUARTE

ESTUDO DO EQUILÍBRIO LÍQUIDO-LÍQUIDO NA EXTRAÇÃO DE ÍONS DE COBALTO USANDO ÁCIDO FOSFÍNICO

São Paulo

2014 
HEITOR AUGUSTO DUARTE

ESTUDO DO EQUILÍBRIO LÍQUIDO-LÍQUIDO NA EXTRAÇÃO DE ÍONS DE COBALTO USANDO ÁCIDO FOSFÍNICO

Dissertação apresentada à Escola Politécnica da Universidade de São Paulo para obtenção do título de Mestre em Engenharia.

São Paulo

2014 


\title{
ESTUDO DO EQUILÍBRIO LÍQUIDO-LÍQUIDO NA EXTRAÇÃO DE ÍONS DE COBALTO USANDO ÁCIDO FOSFÍNICO
}

\author{
Dissertação apresentada à Escola \\ Politécnica da Universidade de São Paulo \\ para obtenção do título de Mestre em \\ Engenharia.
}

Área de concentração:

Engenharia Química

Orientador: Prof. Dr. Pedro de Alcântara Pessôa Filho 
Este exemplar foi revisado e corrigido em relação à versão original, sob responsabilidade única do autor e com a anuência de seu orientador.

São Paulo, 27 de junho de 2014.

Assinatura do autor

Assinatura do orientador Pedeode Pessiatitho

\section{Catalogação-na-publicação}

Duarte, Heitor Augusto

Estudo do equilíbrio líquido-líquido na extração de íons de cobalto usando ácido fosfínico / H.A. Duarte. -- versão corr. -São Paulo, 2014.

$67 \mathrm{p}$.

Dissertação (Mestrado) - Escola Politécnica da Universidade de São Paulo. Departamento de Engenharia Química.

1.Equilibrio líquido-líquido 2.Extração por solvente 3.Separação cobalto níquel 4.Ácido fosfínico I.Universidade de São Paulo. Escola Politécnica. Departamento de Engenharia Química II.t. 


\section{DEDICATÓRIA}

Dedico este trabalho à minha esposa e filho 


\section{AGRADECIMENTOS}

Meus mais sinceros agradecimentos:

Em primeiro lugar, ao meu orientador e amigo, Professor Pedro de Alcântara Pessôa Filho, por sua inesgotável dedicação.

A Márcia Munhoz e Davi Duarte, minha esposa e filho, por seu amor e paciência.

A meus pais, Alberto e Angela Duarte que tanto se dedicaram a mim e meus irmãos, e, que sem seu amor e incentivo, certamente não teria chegado até aqui. Serei eternamente grato.

A toda equipe da Votorantim Metais, por seu entusiasmo e energia despendidos durante este trabalho, com um obrigado especial a Deivid Cavalcanti dos Santos pela sua incansável eficiência.

Aos colegas da Cytec Industries Inc., em particular ao amigo Alex Guadalupe Moreno, que não pouparam esforços no intuito de auxiliar a concretização deste trabalho.

A todos os meus amigos e professores na Universidade de São Paulo que de alguma forma contribuíram para realização deste projeto. 
"Para isso existem as escolas: não para ensinar as respostas, mas para ensinar as perguntas. As respostas nos permitem andar sobre a terra firme. Mas somente as perguntas nos permitem entrar pelo mar desconhecido."

Rubem Alves 


\section{RESUMO}

Este trabalho insere-se no ramo da modelagem de sistemas termodinâmicos complexos, e diz respeito fundamentalmente ao processo de extração de metais (em forma iônica) por solventes, auxiliando a busca de soluções para a otimização do processo. O modelo inicialmente proposto para o comportamento do equilíbrio líquido-líquido do processo de extração de íons metálicos (foram estudados os íons: $\mathrm{Co}^{2+}, \mathrm{Ni}^{2+}, \mathrm{Mg}^{2+}$ e $\mathrm{Mn}^{2+}$ ) mostrou um bom ajuste aos dados experimentais. $\mathrm{Na}$ primeira etapa, investigou-se a dependência da taxa de extração dos íons em relação ao pH de equilíbrio. Outras variáveis como: temperatura, concentração do agente extratante e razão volumétrica $(\mathrm{O} / \mathrm{A})$ foram mantidas constantes e, foram utilizadas soluções monocomponentes e taxas de carregamento do extratante inferiores a $2 \%$. O estudo baseou-se no mecanismo de reação da extração desses íons, e, através do ajuste dos parâmetros principais dessas equações foi possível gerar um modelo para predizer a taxa de extração (E\%) para cada um dos metais estudados. Este primeiro modelo, foi utilizado então, para a obtenção de um segundo modelo que leva em consideração soluções multicomponente de íons concorrentes e taxas de carregamento do extratante próximas a $45 \%$. Parâmetros estes mais coerentes com operações comerciais de separação e produção de níquel e cobalto. $O$ trabalho apresentado mostrou ser possível a utilização de modelos matemáticos que levem estes fatores em consideração, aproximando-se consideravelmente dos valores experimentais, e deste modo permite simulações assertivas de diferentes cenários de processo como: matérias primas, qualidade do produto final e consumo de insumos.

Palavras-chave: Equilíbrio Líquido-Líquido. Extração por Solvente. Separação Cobalto Níquel. Ácido Fosfínico. 


\begin{abstract}
This work is a study on the modeling of the solvent extraction process of metal ions, aiming at finding solutions for process optimization. A model for the liquid - liquid equilibrium accounting for the mass balance in the extraction process of metal ions $\left(\mathrm{Co}^{2+}, \mathrm{Ni}^{2+}, \mathrm{Mg}^{2+}\right.$ and $\left.\mathrm{Mn}^{2+}\right)$ showed an excellent fit to the experimental data . In the first step, the dependence of the rate of extraction of ions as a function of solution $\mathrm{pH}$ was investigated. Other variables such as temperature, concentration of extractant agent (phosphinic acid) and volumetric ratio (organic and aqueous phases) were held constant. Single-component solutions and low loading of extractant were considered. The study was based on the reaction mechanism of extraction of these ions, and by fitting the main parameters of these equations was possible to generate a model for predicting the extraction rate for each of the metals studied. This initial model was then used to obtain a second model which takes into account multicomponent solutions of competing ions and extractant loading rates close to $45 \%$. These parameters are more consistent with commercial operations. The present work showed that using phenomenological models to account for these factors is possible. The model was validated with experimental values. Thus, this work allows for more accurate simulations of different process scenarios concerning raw materials, final product quality and consumption of inputs.
\end{abstract}

Keywords: Liquid -Liquid Equilibrium. Solvent Extraction. Separation Cobalt Nickel. Phosphinic acid. 


\section{LISTA DE ILUSTRAÇÕES}

Figura 3.1 - Ciclo genérico de extração de metais por solvente 10

Figura 3.2 - Extração de metais pelo ácido fosfínico em função do pH. Condições da solução: $[\mathrm{Me}]=0,001 \mathrm{M}$ (como sulfato), [ácido fosfínico] $=0,1 \mathrm{M}, \mathrm{O} / \mathrm{A}=1$, temperatura $=50^{\circ} \mathrm{C}$. Fonte: (Bourget, Sodestrom, Jakovljevic, \& Morrison, 2011) ...29

Figura 3.3 - Extração de cobalto pelo ácido fosfínico em função do pH. Condições da solução: $[\mathrm{Co}]=0,001 \mathrm{M}$ (como sulfato), [ácido fosfínico] $=0,1 \mathrm{M}, \mathrm{O} / \mathrm{A}=1$, temperatura $=50^{\circ}$ C. Fonte: (Bourget, Sodestrom, Jakovljevic, \& Morrison, 2011). .30

Figura 3.4 - Fluxograma básico dos testes de extração contínua conduzidos pela Cytec. Fonte: (Cytec Industries Inc., 2008) 32

Figura 3.5 - Superfícies de resposta encontradas nos experimentos conduzidos por Ferreira. Resultados obtidos em termos de coeficiente de partição (K). Fonte: (Ferreira, 2002) 32

Figura 3.6 - Dependência de D com pH de equilíbrio. Fase orgânica: 1,0 OPPA, Fase aquosa: Solução de sulfato de cobalto $(0,017 \mathrm{M})$ e sulfato de níquel $(0,017 \mathrm{M}) . \mathrm{O} / \mathrm{A}=$ 1. $T=303 K$. Fonte: (Hubli, Vikas, S., N., \& Suri, 2012)

Figura 3.7 - Dependência de D com a concentração de OPPA. Fase orgânica: OPPA em $n$-dodecano, fase aquosa: Solução de sulfato de cobalto $(0,017 \mathrm{M})$ e sulfato de níquel $(0,017 \mathrm{M}) . \mathrm{O} / \mathrm{A}=1$. $T=303 \mathrm{~K}$. Fonte: (Hubli, Vikas, S., N., \& Suri, 2012) .34

Figura 3.8 - Efeito da [Cyanex 272] e pH quando ambos sofrem variação simultaneamente na (a) percentagem de extração do Ln. (b) Ajuste do modelo para mesma situação. Condições experimentais: $0,1 \mathrm{~g} / \mathrm{l}$ de cada $\mathrm{Ln}, \mathrm{O} / \mathrm{A}=1$. Fonte: (Swain \& Otu, 2011) .36

Figura 4.1 - Fluxograma da abordagem realizada para desenvolver modelo para condição multicomponente e alto carregamento do extratante.

Figura 4.2 - Desenho esquemático do reator encamisado empregado nos experimentos de extração de metais por solventes 
Figura 5.1 - Gráfico da taxa de extração em função do pH final da solução aquosa. Condições experimentais: Temperatura $=50^{\circ} \mathrm{C}$, concentração dos metais na solução aquosa inicial $=0,001 \mathrm{M}$, solução extratante $0,1 \mathrm{M}$ de Cyanex em isopar, $\mathrm{O} / \mathrm{A}=1 / 1 \ldots 44$

Figura 5.2 - Gráfico do logaritmo de D em função do pH final da solução aquosa. Condições experimentais: Temperatura $=50^{\circ} \mathrm{C}$, concentração dos metais na solução aquosa inicial=0,001M, solução extratante $0,1 \mathrm{M}$ de ácido fosfínico em isopar, $\mathrm{O} / \mathrm{A}=$ $1 / 1$.

Figura 5.3 - Gráfico do logaritmo de D em função do pH final da solução aquosa. (removendo valores extremos de D). Condições experimentais: Temperatura $=50^{\circ} \mathrm{C}$, concentração dos metais na solução aquosa inicial $=0,001 \mathrm{M}$, solução extratante $0,1 \mathrm{M}$ de ácido fosfínico em isopar, $\mathrm{O} / \mathrm{A}=1 / 1$

Figura 5.4 - Gráficos das funções erro: Ajuste do parâmetro $A_{1}$ relativo à extração dos metais por ácido fosfínico

Figura 5.5 - Gráfico do modelo proposto para a taxa de extração $E(\%)$ para os metais estudados (linhas contínuas). Os pontos identificados referem-se aos valores experimentais da taxa de extração $\mathrm{E}(\%)$ em função do $\mathrm{pH}$ final da solução aquosa. Condições: Temperatura $=50^{\circ} \mathrm{C}$, concentração dos metais na solução aquosa inicial=0,001M, solução extratante $0,1 \mathrm{M}$ de Cyanex em isopar, $\mathrm{O} / \mathrm{A}=1 / 1$. .50

Figura 5.6 - Determinação do tempo necessário para alcançar o equilíbrio da reação de extração de cobalto .52

Figura 5.7 - Equipamento reator utilizado nos experimentos de extração dos metais pelo ácido fosfínico. Nas figuras laterais observa-se a extração de íons de cobalto em diferentes pHs. Conforme o aumento do $\mathrm{pH}$ (de cima para baixo) nota-se a redução da coloração rósea da solução aquosa (inferior) característica da presença de $\mathrm{Co}^{2+}$ e o aumento da coloração azulada da solução orgânica (superior) característica da presença do complexo $\mathrm{R}_{2} \mathrm{Co}$ .54

Figura 5.8 - Gráfico do logaritmo de D em função do pH final da solução aquosa.. Condições experimentais: Temperatura $=60^{\circ} \mathrm{C}$, solução extratante $0,1 \mathrm{M}$ de ácido fosfínico em exxol, $\mathrm{O} / \mathrm{A}=1 / 1$. 
Figura 5.9 - Gráfico do modelo proposto para a taxa de extração $E(\%)$ para os metais estudados (linhas contínuas). Os pontos identificados referem-se aos valores experimentais da taxa de extração $\mathrm{E}(\%)$ em função do $\mathrm{pH}$ final da solução aquosa. Dados obtidos experimentalmente. .57

Figura 5.10 - Gráfico do modelo proposto para a taxa de extração $E(\%)$ para os metais estudados. Linhas contínuas representam o modelo considerando o balanço de massa. Linhas pontilhadas representam o modelo que não considera o balanço de massa. .59

Figura 5.11 - Gráfico do modelo proposto para a taxa de extração $E(\%)$ para os íons de cobalto. Linha contínua representa o modelo considerando o balanço de massa. Linha pontilhada representa o modelo que não considera o balanço de massa.

Figura 5.12 - Gráfico do modelo proposto para a taxa de extração $E(\%)$ para os íons de cobalto. Linha contínua representa o modelo considerando o balanço de massa multicomponente. Pontos $(\square)$ representam dados experimentais obtidos nas mesmas condições da simulação do modelo 62 


\section{LISTA DE TABELAS}

Tabela 3.1 - Refinarias e extratantes utilizados.

Tabela 3.2 - Extratantes utilizados nos processos de separação Ni / Co.

Tabela 3.3 - Parâmetros do teste de extração conduzidos pela Cytec

Tabela 3.4 - Extração Ni / Co por Cyanex 301. Valores de nível mínimo e máximo dos experimentos

Tabela 4.1 - Parâmetros experimentais

Tabela 5.1 - Parâmetros das retas de ajuste para o gráfico de $\log \mathrm{D}$ vs $\mathrm{pH}$ para os metais extraídos

Tabela 5.2 - Determinação do parâmetro $A_{1}$

Tabela 5.3 - Determinação do parâmetro Ksx para os metais em estudo 51

Tabela 5.4 - Dados obtidos no teste de cinética para a extração de cobalto pelo ácido fosfínico

Tabela 5.5 - Dados obtidos nos experimentos de extração com ácido fosfínico dos íons cobalto, magnésio e manganês

Tabela 5.6 - Parâmetros das retas de ajuste para o gráfico de $\log \mathrm{D}$ vs $\mathrm{pH}$ para os metais extraídos

Tabela 5.7 - Determinação do parâmetro $A_{1}$ 56

Tabela 5.8 - Determinação do parâmetro Ksx para os metais em estudo (a partir dos daos experimentais) 


\section{SUMÁRIO}

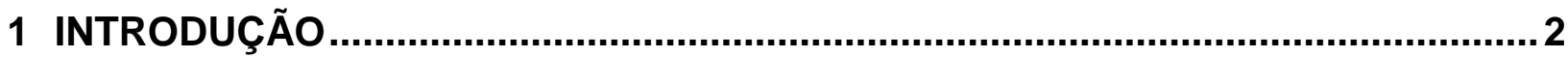

2 OBJETIVOS

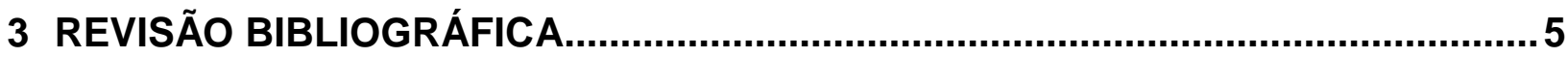

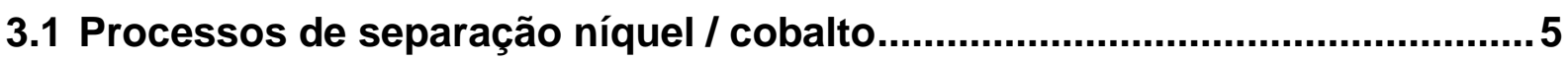

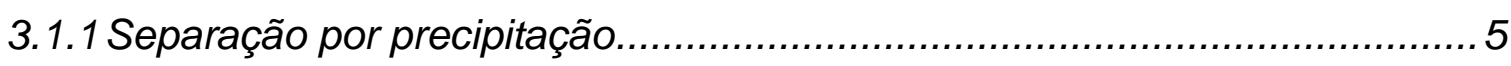

3.1.2 Separação com resinas de troca iônica ................................................. 6

3.1.3 Separação por extração por solventes .................................................. 6

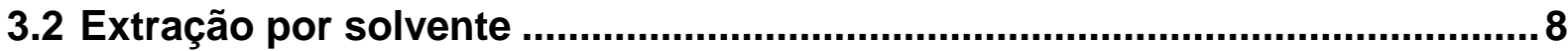

3.2.1 Ciclo genérico do processo de extração por solvente ................................ 9

3.2.2 Bases teóricas da extração por solvente.................................................... 11

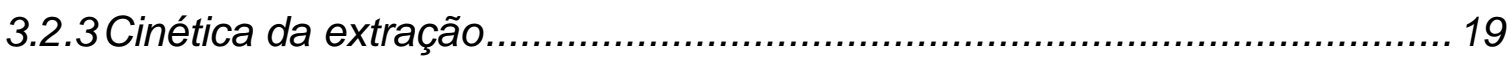

3.2.4 Transferência de massa na extração por solventes ..................................21

3.2.5 Dispersão, continuidade de fase e coalescência.......................................24

3.3 Agentes extratantes utilizados na separação Co-Ni.....................................26

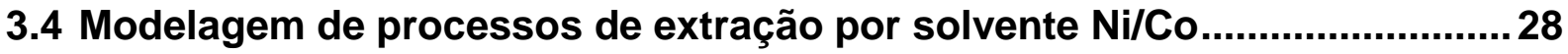

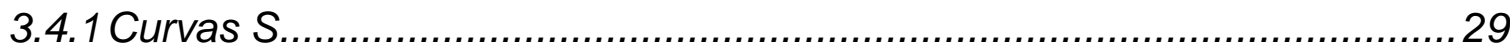

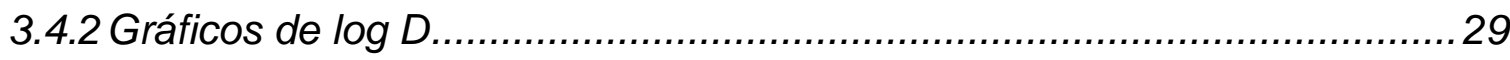

3.4.3 Curvas empíricas - Tratamentos estatísticos..........................................30

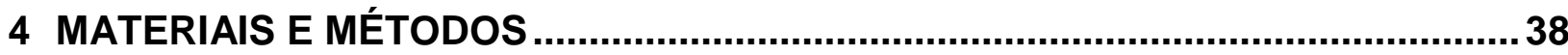

4.1 Condições experimentais utilizadas na literatura para obtenção dos

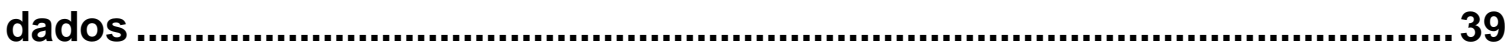

4.2 Reator utilizado para os experimentos ............................................................ 40

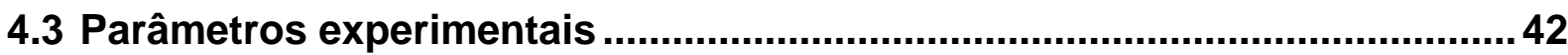

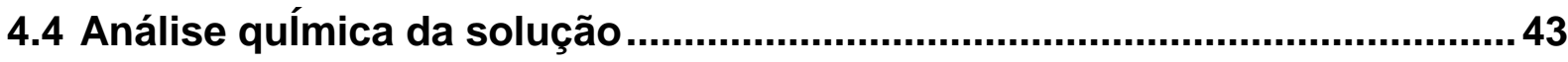

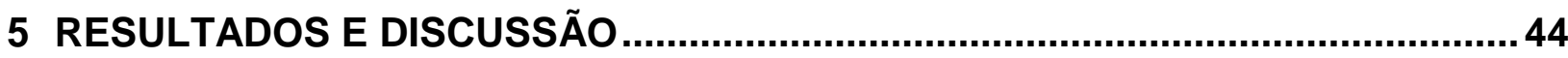

5.1 desenvolvimento do primeiro modelo ..............................................................4

5.1.1 Gráficos da taxa de extração e log $D$ (dados da literatura) ........................ 44

5.1.2 Proposta de modelo para a taxa de extração de metais (dados da



5.1.3 Determinação do valor de Ksx (dados da literatura) ................................50

5.2 Desenvolvimento do modelo de extração para soluções multicomponentes 
5.2.1 Verificação da cinética da reação.

5.2.2 Determinação da taxa de extração e gráfico de $\log D$.

5.2.3 Proposta de modelo para a taxa de extração de metais (dados experimentais) considerando solução monocomponente..............................56

5.2.4 Determinação do valor de Ksx (dados experimentais) ..............................58

5.2.5 Proposta de modelo para taxa de extração considerando solução multicomponente (concorrência dos metais) ...........................................58

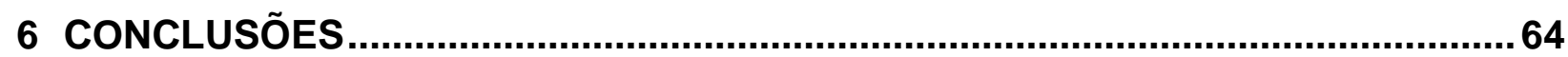

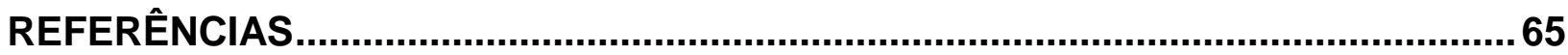

ANEXO A - CARACTERÍSTICAS FÍSICO-QUÍMICAS DO ÁCIDO DIALQUIL

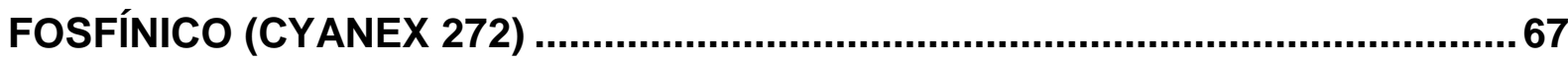




\section{INTRODUÇÃO}

Há cento e quarenta anos, em 1872, Berthelot and Jungfleisch enunciaram, pioneiramente, as leis que governam a distribuição de metais entre duas fases imiscíveis (Baird, Hanson, \& Lo, 1991). Desde então, estes conceitos tem sido aplicados a inúmeros campos da ciência.

Já na década de quarenta, impulsionados pela indústria bélica, pesquisadores dedicaram esforços para o desenvolvimento de processos de separação e recuperação de materiais radioativos. Iniciava-se então, a utilização da extração por solvente em operações de larga escala industrial. As inovações tecnológicas e o avanço no entendimento dos fundamentos envolvidos permitiram que estas técnicas começassem a ser aplicadas amplamente nos processos metalúrgicos, especialmente, no desenvolvimento de rotas para o tratamento e recuperação de metais não ferrosos (Ritcey, 2006).

Atualmente, a crescente competitividade do mercado moderno, influenciada, principalmente, por fatores econômicos e sociais impulsionam, de maneira acelerada, o desenvolvimento tecnológico das empresas e indústrias. A sobrevivência e sustentabilidade das corporações neste cenário dependem, fundamentalmente, de uma estratégia voltada para a inovação e o contínuo aperfeiçoamento dos processos existentes. Para uma empresa, portanto, o aprofundamento do conhecimento e a modelagem de seus processos e sistemas são de grande interesse, pois permitem a simulação de possíveis cenários e a eventual otimização de parâmetros, reduzindo sensivelmente a margem de erros e permitindo tomadas de decisão mais efetivas do ponto de vista econômico e estratégico.

Este trabalho insere-se no ramo da modelagem de sistemas termodinâmicos complexos, e diz respeito fundamentalmente ao processo de extração de metais (em forma iônica) por solventes, auxiliando a busca de soluções para a otimização do processo. Os modelos a serem estudados devem-se basear em conceitos e fundamentos termodinâmicos aplicados, especificamente, ao equilíbrio de fases de sistemas líquido-líquido. 
Espera-se que os resultados obtidos sugiram, por exemplo, modificações nos parâmetros de operação ou nos procedimentos operacionais do processo estudado, introduzindo novos modelos de controle e de otimização do processo - por exemplo (mas não somente) pela simulação de diferentes cenários para os parâmetros de processo da refinaria. 


\section{OBJETIVOS}

O escopo central deste trabalho é estudar o equilíbrio líquido-líquido de sistemas contendo íons metálicos, a fim de ampliar o conhecimento dos fenômenos termodinâmicos que envolvem as operações unitárias de extração por solventes aplicadas à hidrometalurgia. Para isso, foi desenvolvida uma abordagem que acopla o cálculo do balanço de massa ao equilíbrio químico de reação do solvente extrator com os íons metálicos - equilíbrio este que, para o caso de extratantes ácidos, é fortemente dependente do $\mathrm{pH}$ do sistema. 


\section{REVISÃO BIBLIOGRÁFICA}

\subsection{PROCESSOS DE SEPARAÇÃO NÍQUEL / COBALTO}

A separação do cobalto a partir de uma solução aquosa de níquel tem sempre sido um problema para a hidrometalurgia (Flett D. S., 2004). Suas posições adjacentes na tabela periódica resultam num comportamento químico muito similar, principalmente, quando em solução aquosa. Assim, o desenvolvimento de rotas de separação e purificação não é trivial.

\subsubsection{Separação por precipitação}

A precipitação ou oxidação seletiva foram os primeiros processos a serem utilizados para a separação níquel / cobalto. Estes processos são utilizados tanto em meio clorídrico quanto em meio sulfatado. Este tipo de tecnologia ainda é usada atualmente, apesar de, comprovadamente, o processo de extração por solvente alcançar maiores taxas de separação e menores custos operacionais (Ritcey, 2006).

A precipitação seletiva por compostos de sulfeto tem sido usada para purificação de soluções de níquel contendo cobalto. Reagentes como ferro, sulfeto de cobalto e enxofre elementar são utilizados para precipitação em pH entre 1 e 5 e temperaturas acima de $80^{\circ} \mathrm{C}$ (Flett D. S., 1987). Exemplos de empregos comerciais destas técnicas são encontrados nas refinarias da Sherritt Gordon nas Filipinas e em unidades da Queensland Nickel na Austrália.

Refinarias no Canadá das empresas Inco e Falconbridge, Jin Chuan na China e Amax nos EUA, são exemplos industriais de processos que utilizam técnicas de precipitação oxidativa para separação de cobalto do níquel. Devido à similaridade dos diagramas Eh-pH de seus íons, são necessários oxidantes fortes como gás cloro, persulfato de amônio, compostos de peroxigênio, ácido de Caro ou ozônio (Flett D. S., 1987). 


\subsubsection{Separação com resinas de troca iônica}

Separação níquel e cobalto por troca iônica é mais facilmente conseguida a partir de soluções clorídricas, onde o cobalto tem a tendência de formar complexos aniônicos de cloro $\left(\mathrm{CoCl}_{3}{ }^{-}, \mathrm{CoCl}_{4}^{-}\right)$e o níquel não. Esses princípios ainda não são utilizados comercialmente (Flett D. S., 2004).

A troca iônica com o uso de agentes quelantes pode ser empregada. Resinas quelantes produzidas originalmente pela empresa Dow Química, pode remover níquel seletivamente do cobalto (Grinstead \& Tsang, 1983). Estas resinas são baseadas numa matriz macroporosa de divinilbenzeno e poliestireno. As empresas Inco em Port Colborne (EUA) e Chambishi na Zâmbia utilizam esta tecnologia em caráter experimental.

\subsubsection{Separação por extração por solventes}

O sucesso no desenvolvimento de processo de separação por solventes para o urânio, nos anos de 1950, impulsionou a formação de diversos grupos de estudo na busca de processos semelhantes aplicáveis a outros metais de interesse. $\mathrm{Na}$ ocasião, dentre esses metais de interesse estavam o níquel e o cobalto. No início dos anos 1960 até 1975, grupos de pesquisa no Canadá, Estados Unidos, GrãBretanha, Rússia, Holanda, Israel, Noruega, Suécia e França (Ritcey, 2006) se empenharam em desenvolver uma tecnologia que incorporasse a extração por solventes aos processos de obtenção de níquel e cobalto. Mais tarde, com o amadurecimento desses estudos, plantas operacionais foram instaladas no Brasil, Bélgica, Suécia, Finlândia, China, África do Sul, Japão e Austrália utilizando esta tecnologia.

Devido ao menor custo de operação e às excelentes taxas de separação, o processo de separação por solventes para a obtenção de níquel e cobalto é o mais utilizado na indústria, e o estudo do comportamento e dos fenômenos envolvidos nesse processo continuam a ser realizados por pesquisadores de todas as partes do mundo. 
A separação níquel / cobalto por extração por solvente tem sido intensivamente estudada nos últimos 30 anos. Grande parte das plantas comerciais que utilizam este processo tem o ácido dialquil fosfínico como reagente extratante (Flett D. S., 2004). Os principais motivos pelos quais a extração por solvente é preferencialmente utilizada em processos comerciais são:

- Menor custo com reagentes,

- Menor custo com mão de obra,

- Menor consumo de energia,

- Menor impacto ambiental do processo e resíduos gerados,

- Maior coeficiente de separação cobalto / níquel,

- Maior pureza dos produtos finais.

Solventes do grupo das alquilaminas são os geralmente escolhidos para separação de cobalto do níquel em meio clorídrico, assim como no processo produtivo da empresa francesa Eramet e na empresa Falconbridge na Noruega (Burkin, 1987). Solventes do grupo dos ácidos alquilfosforados são aplicados na separação de cobalto do níquel em meios sulfatados diluídos. A primeira empresa a utilizar esta classe de reagente foi a Anglo Platinum Ltda na sua refinaria Rustenberg Base Metal Refinery na África do Sul (Clemente, Dewar, \& Hill, 1980).

Em processos cuja concentração de cobalto é alta em relação à concentração de níquel, notadamente em processos que utilizam minério laterítico como matériaprima, fatores de separação cobalto / níquel acima de 1000 são exigidos, e somente os ácidos fosfínicos são capazes de obter tal coeficiente de separação (Rickelton \& Nucciarone, 1997).

A Tabela 3.1 apresenta as principais refinarias do mundo que utilizam processos de separação de cobalto do níquel e respectivos reagentes utilizados.

Tabela 3.1 - Refinarias e extratantes utilizados

\begin{tabular}{llll}
\hline País & Empresa & Reagente & $\begin{array}{l}\text { Nome } \\
\text { comercial }\end{array}$ \\
\hline \multirow{2}{*}{ Austrália } & Queensland Nickel & Quelante & LIX84QN \\
& Cawse Murrin & Quelante & LIX84I \\
Bélgica & Bulong & Ácido Fosfínico & Cyanex 272 \\
Brasil & Metallurgie Hoboken & Ácido Fosfínico & Cyanex 272 \\
\hline
\end{tabular}




\begin{tabular}{llll}
\hline País & Empresa & Reagente & $\begin{array}{l}\text { Nome } \\
\text { comercial }\end{array}$ \\
\hline Canadá & Eldorado Nuclear & Ácido Fosfórico & DEHPA \\
China & Jin Chuang Refinery & Ácido Fosfórico & P204 \\
Finlândia & Outukumpu & Ácido Fosfínico & Cyanex 272 \\
França & Societe Le Nickel & Amine-HCl & Amine-HCl \\
Japão & Sumitomo Nippon & Ácido & Cersatic \\
Noruega & Falconbridge & Amine-HCl & Amine-HCl \\
África do Sul & Rustenberg Refiners & Ácido Fosfórico & DEHPA \\
Suécia & Gullspang & Amine-HCl & Amine-HCl \\
EUA & Pyrites Sec Corp & Ácido Fosfórico & LIX64N, \\
\hline
\end{tabular}

Fonte: (Ritcey, 2006)

\subsection{EXTRAÇÃO POR SOLVENTE}

O processo de extração por solvente (ou extração líquido-líquido) aplicado num processamento metalúrgico é, de fato, um processo de equilíbrio que pode ser descrito de forma simples por uma equação conforme abaixo:

$$
M_{\text {aq }}+E_{\text {org }} \rightleftharpoons M E_{\text {org }}
$$

Na primeira etapa o metal de interesse, $M$, é transferido de uma fase aquosa para uma fase orgânica, E, (quando necessário, os índices aq e org serão utilizados para representar as fases aquosa e orgânica, respectivamente) como um complexo, ME, neste caso, o processo requer que o equilíbrio esteja deslocado para a direita. $\mathrm{Na}$ segunda etapa, o que se deseja é o inverso, isto é, o metal é transferido da fase orgânica para fase aquosa, então, nesta etapa, o equilíbrio é deslocado para a esquerda. A primeira etapa é chamada de extração e a segunda, re-extração (termos provenientes do inglês: extraction e stripping).

Basicamente, portanto, a extração por solvente de um metal é uma operação que requer o controle do deslocamento da reação de equilíbrio entre as etapas de extração e re-extração. A simplicidade deste conceito é particularmente atrativa para aplicação em processos metalúrgicos e de purificação. 
Contudo, a compreensão dos mecanismos dos sistemas de extração pode tornar-se complexa, pois depende de diversos fatores, entre os quais o tipo de agente extratante e a composição da fase aquosa. Nos tópicos seguintes, serão explicitados os principais conceitos teóricos envolvidos nesse processo, bem como suas implicações nos processos comerciais.

\subsubsection{Ciclo genérico do processo de extração por solvente}

O circuito de extração por solvente, de forma geral, é mostrado esquematicamente na Figura 3.1. A solução aquosa contendo os metais e a solução contendo o solvente são alimentadas, geralmente, de forma contracorrente, em contatores em que as duas fases são misturadas. Nesta etapa, o metal de interesse é transferido da fase aquosa para a fase orgânica. Após a separação das fases (decantação), a fase aquosa purificada, também chamada de rafinado, é enviada para tratamentos posteriores.

A partir da fase de extração, o solvente carregado é enviado para outro contator onde é lavado com uma solução aquosa, cujo intuito é remover pequenas quantidades de metais ou impurezas co-extraídas no estágio de extração. A solução aquosa final deste processo é enviada para posteriores estágios de tratamento e/ou recuperação.

Após a lavagem, o solvente carregado passa para o estágio no qual o metal é removido (estripado) a partir da fase orgânica por alguma solução aquosa apropriada, produzindo geralmente, uma solução bastante concentrada de sal do metal, a qual então vai para um processamento adicional para a produção do metal.

O solvente por sua vez é reciclado de volta para a fase de extração, se necessário, pode passar por etapas de tratamento ou purificação antes de entrar novamente na fase de extração. 


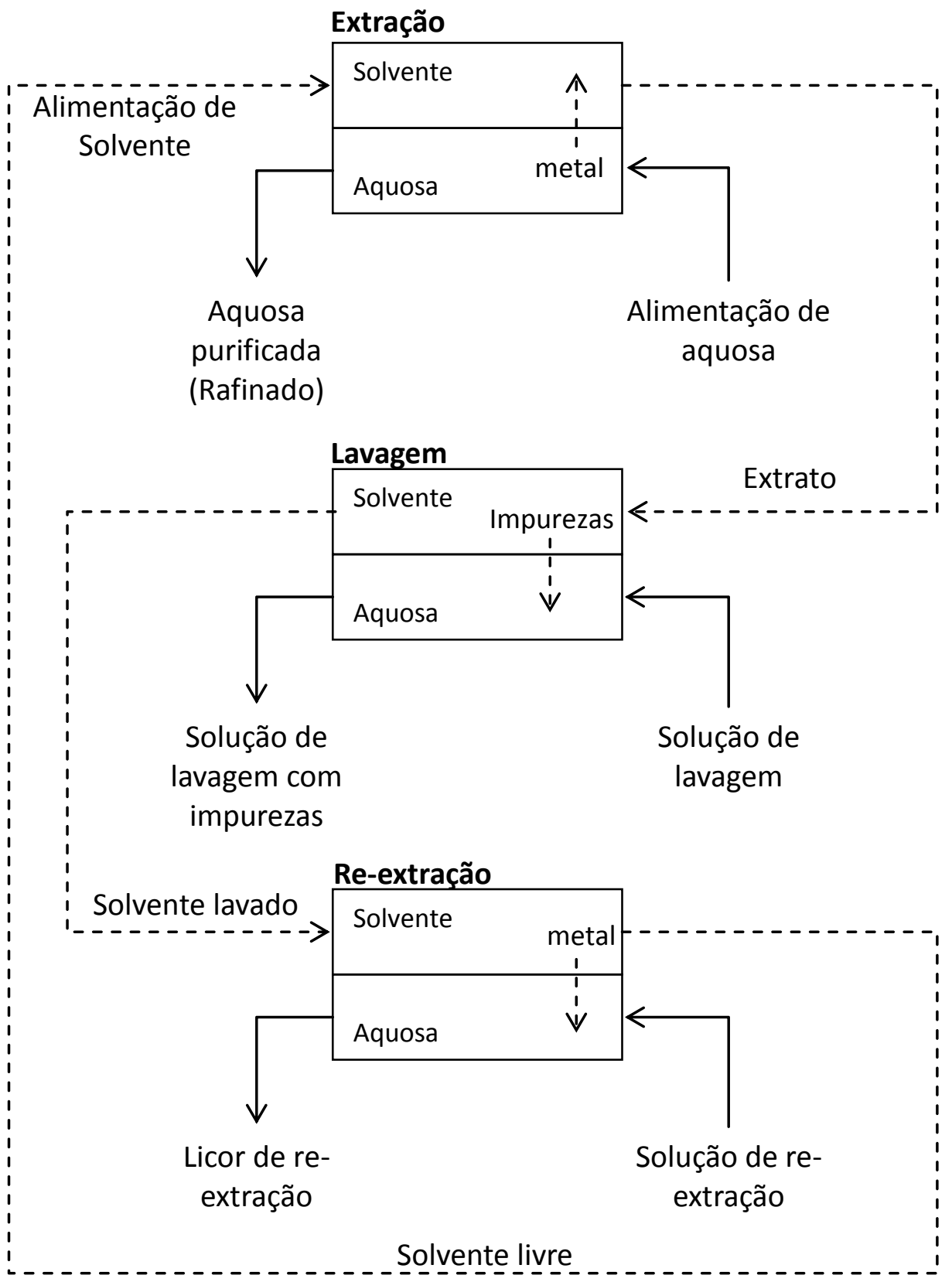

Figura 3.1 - Ciclo genérico de extração de metais por solvente

Cada uma das três etapas descritas, extração, lavagem e re-extração (termos provenientes do inglês extraction, scrubbing, stripping) podem envolver mais de um estágio de contato. Para a separação níquel / cobalto, por exemplo, são necessários geralmente, quatro estágios ideais de extração, três estágios de lavagem e três estágios de re-extração (Cytec Industries Inc., 2008). 


\subsubsection{Bases teóricas da extração por solvente}

Quando uma fase aquosa contendo um metal é agitada com uma fase orgânica na qual o metal é extraído, haverá uma distribuição deste metal entre as duas fases. A distribuição pode ser de natureza química ou física, dependendo das espécies envolvidas no sistema. Os processos físicos são aqueles que envolvem a extração de moléculas covalentes simples, não carregadas, tais como haletos de arsênio (III), antimônio (III), e mercúrio (II), em solventes orgânicos, tais como o tetracloreto de carbono. Em tais casos, a lei de distribuição de Nernst é geralmente válida, e o coeficiente de distribuição, $\mathrm{K}_{\mathrm{D}}$, é independente tanto da concentração total do soluto (metal) quanto da relação de fases (razão entre os volumes das fases aquosa e orgânica). Portanto, $K_{D}$ é simplesmente a proporção de concentração de soluto (S) nas duas fases:

$$
K_{D}=\frac{(S)_{o r g}}{(S)_{a q}}
$$

Assim, a lei de Nerst neste caso, depende apenas da solubilidade da espécie metálica na fase de solvente. Não há interações químicas entre as espécies de metal e a fase orgânica, isto é, o soluto é de forma química idêntica em ambas as fases.

Exceto para os raros casos como os descritos acima, a extração por solvente envolve algum tipo de reação química entre as espécies presentes na fase aquosa e um ou mais componentes da fase orgânica. Nestes casos, a lei de distribuição de Nernst não necessariamente se aplica, contudo, a equação básica utilizada em estudos de extração com solventes assemelha-se a ela.

Normalmente, um íon de metal existe em solução aquosa como um íon hidratado, com pouca ou nenhuma tendência a ser transferido para uma fase orgânica. Deste modo, a fim de se alcançar a transferência do íon metálico é necessário que este seja modificado de alguma maneira. Para converter o íon metálico em uma espécie extraível, sua carga exige neutralização, e, uma parte ou toda a sua água de hidratação tem de ser substituída por outra molécula ou íon. 
Estas condições podem ser alcançadas pela complexação do íon metálico com um ín de carga oposta para formar uma espécie neutra, o que ao mesmo tempo substitui a água de hidratação ao redor do íon metálico, pela formação de complexos que também proporcionam a formação de uma espécie neutra com o extratante, ou ainda, substituindo a água de hidratação por moléculas do solvente. De maneira geral, pode-se considerar o processo global como uma conversão de uma espécie hidrófila em espécies hidrofóbicas. A complexação do íon metálico pode ser vista como um processo em que as moléculas de água hidratadas são substituídas por outras moléculas mais complexas. Dessa forma, todas as reações de complexação são, então, a rigor, reações de substituição.

A natureza das espécies metálicas extraíveis é, portanto, de fundamental importância nos sistemas de extração de metal e, por isso, é utilizada para classificar esses sistemas. As classes consideradas são: (i) sistemas que envolvem a formação de um composto, onde o agente extratante pode ser de base quelante ou ácida, (ii) sistemas que envolvem associação de íons, (iii) sistemas que envolvem a solvatação do íon metálico.

3.2.2.1 Sistemas envolvendo formação de compostos (extratantes de base quelante)

A equação mais simples que pode ser escrita para ilustrar a extração do íon de metal $M$ por um extratante, $R H$, é:

$$
M_{a q}^{n+}+m R H_{\text {org }} \rightleftharpoons M R_{n}(R H)_{(m-n) o r g}+n H_{a q}^{+}
$$

O fator $m$ remete à formação de dímeros e/ou polímeros no extratante, fenômeno mais comum em extratantes de base ácida (Kislik, 2012). Esta equação genérica é na verdade o resultado de etapas intermediárias nas quais há a partição do extratante entre as fases orgânica e aquosa, em seguida o extratante é ionizado, e então, o ânion reage com o íon metálico formando o complexo neutro e por fim, há a partição deste complexo nas duas fases: 
Descrito desta maneira, o mecanismo de extração do metal é totalmente dependente das reações químicas na fase aquosa e, por isso, requer ao menos que o extratante seja razoavelmente solúvel na fase aquosa. Outra maneira de interpretar o que acontece fisicamente no sistema de extração, considerando o extratante como extremamente insolúvel na fase aquosa, é pressupor que as reações ocorrem somente na interface, e assim, o mecanismo é dependente das isotermas de adsorção relacionando as concentrações interfaciais do extratante e do complexo metálico com as concentrações no cerne das fases.

A equação (3.3) é muito semelhante à equação (3.1), que por sua vez assemelhase, também, ao processo de troca iônica sólido-líquido, no qual $R H$ é equivalente à uma resina de troca iônica. Por conta dessa peculiaridade a extração por solventes também é chamada como troca íon-líquido. Assim, os sistemas utilizando quelante e extratantes ácidos são chamados de sistemas de trocas de cátions, enquanto aqueles utilizando extratantes à base de amina são sistemas de troca de ânions.

É importante salientar que o processo em questão é fundamentalmente um processo de equilíbrio. Este aspecto é de suma importância uma vez que a posição do equilíbrio, como descrita pela equação (3.3), e a taxa em que o equilíbrio é atingido, definem o tamanho da planta de extração e por consequência a viabilidade econômica do projeto.

A equação (3.3) indica que a extração de metal descrita por essa equação é fortemente dependente do equilíbrio de $\mathrm{pH}$ da fase aquosa. Assim, se o $\mathrm{pH}$ é reduzido, ou seja, a concentração de íon de hidrogênio é aumentada, a extração do metal diminuirá, uma vez que o equilíbrio do sistema será deslocado para a esquerda. Reciprocamente, quando o pH aumenta, a extração de metal é aumentada também. Obviamente, há um limite imposto pela hidrólise do próprio metal. A extração é também dependente da estabilidade dos complexos de metais formados, que são uma função, em parte, do agente extrator.

Para os sistemas em que a extração envolve somente concentrações baixas de metal, a quantidade do íon hidrogênio formado será pequena, e irá mudar muito pouco o pH do sistema. Por outro lado, a extração de grandes quantidades de metal, como em um processo comercial, produzirá correspondentemente grande quantidade do íon hidrogênio. 
Por exemplo, na extração de cobalto por um reagente monobásico, $R H$, a extração de um mol de cobalto produzirá dois mols de íons hidrogênio:

$$
\mathrm{CoSO}_{4}+2 \mathrm{RH} \rightleftharpoons \mathrm{Co}(\mathrm{A})_{2}+\mathrm{H}_{2} \mathrm{SO}_{4}
$$

$\mathrm{Na}$ extração do íon férrico, três mols do íon de hidrogênio serão produzidos para cada mol de Fe(III) extraído.

$$
\mathrm{Fe}_{2}\left(\mathrm{SO}_{4}\right)_{3}+6 \mathrm{RH} \rightleftharpoons 2 \mathrm{Fe}(\mathrm{A})_{3}+3 \mathrm{H}_{2} \mathrm{SO}_{4}
$$

No caso em que a concentração desses metais for suficientemente alta, de modo que os íons hidrogênio gerados alterem o pH do sistema, o limite de extração será atingido rapidamente. Para conseguir alcançar alta carga de carregamento do solvente pelo metal (situações industriais reais), o íon hidrogênio produzido deve ser neutralizado de alguma forma, e isto é conseguido introduzindo agentes básicos ao sistema, por exemplo, hidróxido de sódio ou hidróxido de amônio. O agente neutralizante deve ser convenientemente escolhido de maneira que o cátion gerado não influencie na extração dos metais de interesse.

A quantidade de metal extraído por um solvente pode ser determinado simplesmente por uma análise da fase aquosa. Consideremos novamente a extração de cobalto como ilustrado pela equação (3.3). A quantidade de metal extraído pode ser determinada pela análise da fase aquosa (rafinado). Desde que se conheça a concentração inicial do metal, é possível calcular as concentrações na fase orgânica, fazendo o balanço de massa do sistema. Assim, na condição experimental considerada, a proporção de metal nas duas fases estará determinada, o que fornece uma boa indicação da extensão na qual o equilíbrio da equação (3.3) foi deslocado para a direita.

Esta relação da distribuição de um metal, determinada analiticamente entre uma fase aquosa e uma fase orgânica, é conhecida como o coeficiente de extração, ou coeficiente de distribuição, $D$, e é definido como:

$$
D=\frac{\text { concentração do metal na fase or gânica }}{\text { concentração do metal na fase aquosa }}
$$


As concentrações de metal são determinadas analiticamente, e são concentrações totais do metal, em qualquer forma, em cada fase. Esta relação é básica para todos os estudos de extração de solvente (Ritcey, 2006) e fornece muitos dados a respeito do processo de extração de solvente.

Para um sistema genérico como o descrito na equação (3.3) é possível, ainda, determinar a constante de equilíbrio, $K s x$, da reação de extração usando a seguinte relação (Koretsky, 2007):

$$
K_{s x}=\frac{\left[M R_{n}(R H)_{m-n}\right]_{o r g} \cdot\left[H^{+}\right]_{a q}^{n}}{\left[M^{n+}\right]_{a q} \cdot[R H]_{o r g}^{m}}
$$

A equação (3.) é válida somente assumindo que as atividades dos componentes são iguais às suas respectivas concentrações. A rigor devem-se considerar as atividades das várias espécies envolvidas na extração do metal, ao invés das concentrações. Porém, nos casos em que as concentrações de metal são baixas, a atividade e a concentração podem ser consideradas para todos os efeitos, como sendo a mesma. Contudo, nas aplicações práticas nas quais as concentrações de sal são altas $(>0.1$ M) diferenças substanciais entre a atividade e a concentração poderão ocorrer e portanto, esse efeito deverá ser levado em consideração.

Devido ao fato de praticamente toda a bibliografia sobre o tema usar concentrações ao invés de atividade (isso faz as equações muito mais simples para lidar), as discussões que se seguem somente levarão em consideração as concentrações, contudo, quando for oportuno, as respectivas atividades dos componentes serão introduzidas.

Substituindo o coeficiente $D$ na equação (3.), obtém-se:

$$
K_{s x}=D \cdot \frac{\left[H^{+}\right]^{n}}{[R H]^{m}}
$$

Rearranjando:

$$
D=K_{s x} \cdot \frac{[R H]^{m}}{\left[H^{+}\right]^{n}}
$$


Esta relação é particularmente importante nos estudos de extração por solvente, pois demonstra que o coeficiente de extração $D$, que é determinado experimentalmente, é então proporcional à constante de equilíbrio da reação, pela emésima potência da concentração do extratante na fase do solvente, e é inversamente proporcional à enésima potência da concentração do íon hidrogênio na fase aquosa. E ainda, demonstra que $K_{s x}$ pode ser calculada a partir de dados experimentais.

A equação (3.) pode ser ainda rearranjada de maneira a se obter:

$$
\log D=\log K s x+m \log [R H]_{\text {org }}+n p H
$$

A equação (3.) é fundamental nos estudos relacionados à extração por solvente, pois demonstra que o logaritmo do coeficiente de distribuição é dependente linearmente do $\mathrm{pH}$ final da solução aquosa, desde que duas premissas sejam atendidas:

- (1) Ksx deve ser constante. Esta premissa é razoável para os casos em que a temperatura é mantida constante. Se as propriedades físicas de solubilidade e reações interfaciais forem mantidas, então Ksx será constante para diferentes valores de $\mathrm{pH}$.

- (2) a concentração do agente extratante na fase orgânica é constante. Em tese, se há extração de metal, a concentração do agente extratante não permanecerá constante na fase aquosa (uma vez que vai sendo consumido), porém, para eliminar esse efeito, usa-se uma concentração de extratante muito maior do que a necessária estequiometricamente para se extrair o metal, de modo que a variação na concentração do extratante seja insignificante.

Além do coeficiente de distribuição, é comum aos estudos de extração por solvente a utilização da taxa de extração do metal, E, obtida fazendo-se:

$$
E(\%)=1-\frac{\text { concentração final do metal na aquosa }}{\text { concentração inicial do metal na aquosa }} \times 100
$$

Não é difícil deduzir matematicamente que $E$ e $D$ se relacionam da seguinte maneira: 


$$
E(\%)=\frac{D \frac{\text { Vorg }}{\text { Vaq }}}{1+D \frac{\text { Vorg }}{\text { Vaq }}} \times 100
$$

Em que Vorg e Vaq são, respectivamente, os volumes das fases orgânica e aquosa.

Além da forte dependência de $D$ em relação ao $\mathrm{pH}$ da fase aquosa e à concentração do agente extratante na fase orgânica, outros fatores devem ser considerados caso a caso, pois são bastante específicos para cada sistema estudado (Ritcey, 2006). São eles: a estabilidade do complexo de metal, a distribuição deste complexo de metal extraível entre as duas fases e a taxa de ionização do extratante. Outros fatores, tal como tensão interfacial, viscosidade, etc., também podem influenciar o sistema e, quando conveniente, devem ser considerados.

\subsubsection{Sistemas envolvendo formação de compostos (extratantes de base ácida)}

Os mecanismos de extração envolvendo os extratores ácidos são idênticos aos estudados com extratores quelantes, inclusive, a equação (3.3) é válida, também, para estes casos. Contudo, alguns aspectos relativos ao agente extrator de base ácida podem ser mais complicados para descrever, de um modo geral, do que com extratantes quelantes. As mesmas considerações qualitativas se aplicam, tais como a influência no $\mathrm{pH}$, concentração de extratante e concentração do íon metálico. Contudo, os fatores que afetam a ordem da extração do metal e a composição dos complexos metálicos extraíveis, por exemplo, são muito menos previsíveis.

A extração de metais por ácidos organofosforados, ácidos carboxílicos e ácidos sulfônicos é mais afetada pelas propriedades do estado do solvente do que é para extratores de base quelante. A literatura mostra que, tanto o ácido organofosforado e carboxílico muitas vezes formam dímeros ou polímeros na fase orgânica, principalmente como resultado da ligação de hidrogênio, a qual pode afetar consideravelmente suas propriedades extrativas (Flett D. S., 1967). A solvatação das espécies extraídas é também um fator a ser considerado. 
O sistema em estudo neste trabalho emprega justamente um extratante de base ácida (ácido dialquil fosfínico) na extração de metais. Os ácido fosfínicos são considerados ácidos fracos e a formação de dímeros e polímeros na fase orgânica pode ser inibida pela utilização de um diluente apropriado. Modificadores de fase também são utilizados comercialmente para inibir esses efeitos (Olivier, 2011).

\subsubsection{Sistemas envolvendo associação de íons}

Os sistemas que empregam associação de íons são ainda mais difíceis de analisar do que os previamente discutidos. Esta dificuldade surge como um resultado da falta de compreensão das espécies em soluções concentradas, isto é, soluções cuja concentração excede $0,1 \mathrm{M}$ de força iônica. Assim, a equivalência da concentração geralmente aceita em relação à atividade (ainda que em baixas concentrações) não pode ser aplicada nestes casos (Ritcey, 2006). A expressão quantitativa derivada para agentes quelantes e sistemas extratores ácidos torna-se essencialmente qualitativa nos sistemas de associação de íons. Assim, grande parte do trabalho feito em tais sistemas do ponto de vista mais prático é invariavelmente de natureza empírica.

Contudo, é importante relatar que este tipo de processo pode ser aplicado comercialmente na separação níquel / cobalto, principalmente em soluções clorídricas. Um exemplo de extratante deste tipo são as aminas, a reação de extração de cobalto nestes sistemas pode ser representada pela seguinte equação:

$$
\mathrm{CoCl}_{4}^{2-}+2 \mathrm{R}_{3} \mathrm{NH}^{+} . \mathrm{Cl} \rightleftharpoons\left(\mathrm{R}_{3} \mathrm{NH}^{+}\right)_{2} \cdot \mathrm{CoCl}_{4}^{2-}+\mathrm{Cl}^{-}
$$

Outros fatores de difícil análise podem influenciar a extração por solvente em sistemas dessa natureza, como, o número de átomos de carbono na cadeia e a própria natureza da cadeia carbônica na molécula do extratante.

\subsubsection{Sistemas envolvendo solvatação}

Outro importante grupo de sistema extrativo é baseado no poder de extratantes orgânicos que contém oxigênio para solvatar moléculas inorgânicas ou complexos. Através da solvatação a solubilidade de espécies inorgânicas em fases orgânicas pode ser aumentada consideravelmente. 
Há dois grandes grupos de extratantes que se pode destacar: aqueles contendo átomo de oxigênio ligado a carbonos como os éteres (C-O-C), ésteres (-COOR), alcóois $(\mathrm{C}-\mathrm{OH})$ e cetonas $(\mathrm{C}=\mathrm{O})$ e, aqueles contendo oxigênio ligado ao fósforo como os ésteres alquil-fosfatos $(\equiv \mathrm{P}=\mathrm{O})$.

O mais conhecido e mais usado dos ésteres organofosforados é, indubitavelmente, o tri-n-butil fosfato (TBP). Por conta da sua larga utilização em processos nucleares, há bastante informação sobre ele e reagentes similares (Bess \& Schulz, 1984).

Como resultado da complexidade da extração por solventes empregando extratantes de solvatação, e, somando o fato de que este trabalho não pretende utilizar este tipo de tecnologia, não serão discutidas abordagens matemáticas quantitativas.

\subsubsection{Cinética da extração}

Apesar de a extração por solvente ser um processo baseado no equilíbrio do sistema reacional, a velocidade com a qual este equilíbrio é atingido é também extremamente importante, pois a cinética do sistema controla, entre outros fatores, 0 rendimento do processo.

Sistemas extrativos cuja cinética é muito rápida, por exemplo, permitem a utilização de contatores que têm tempos de retenção na ordem de segundos, (como centrífugas) e permitem vazões elevadas. Por outro lado, em sistemas cuja cinética é mais lenta há a necessidade de várias etapas de extração com alto tempo de retenção, o que pode, em princípio, inviabilizar determinados projetos.

Na maioria dos casos, a extração de metais é governada por transferência de massa e difusão que são, em geral, bastante rápidas (Flett D. S., 2004). A maioria das reações químicas que envolvem reações do tipo iônicas é rápida, enquanto que as taxas de reações que envolvem a formação de quelantes podem variar em uma faixa considerável. Outros fatores que afetam as taxas de extração são as viscosidades das fases, a agitação e a temperatura do sistema.

Em um sistema heterogêneo, tal como na extração por solvente, a taxa de extração de um metal dependerá, em grande parte, da área de superfície da fase dispersa que, por sua vez, depende essencialmente das condições iniciais da agitação das fases. 
A área de superfície da fase dispersa irá depender da quantidade de agitação, isto é, da quantidade de energia que ingressa no sistema. No entanto, não se deve concluir que quanto maior for a agitação maior será a taxa de extração do metal. $O$ excesso de entrada de energia pode resultar na formação de emulsões estáveis ou semiestáveis (Olivier, 2011). Além disso, diminuir o tamanho das bolhas da fase dispersa pode resultar em tornar as bolhas semelhantes a esferas rígidas. Nesta condição, não há circulação interna dentro das esferas, novas superfícies não são produzidas, e o extrator dentro da esfera não pode chegar à superfície para reagir com os íons metálicos. Consequentemente, a taxa de extração se torna lenta.

Como em outros tipos de processo, a etapa mais lenta da reação de extração será determinante para a velocidade global. Notadamente, a formação de um complexo de metais extraíveis é muito mais lenta do que a taxa à qual o complexo é extraído para a fase orgânica (Ritcey, 2006), assim, a formação do complexo é, em geral, a etapa determinante no sistema reacional de extração de metais por solventes.

A taxa à qual o equilíbrio é alcançado entre as duas fases, que inicialmente não se encontram em equilíbrio depende do grau de extensão em que as concentrações das duas fases inicialmente diferem daquelas alcançadas no estado de equilíbrio. Esta é fixada pelo coeficiente de extração para esse sistema em particular: em outras palavras, depende do potencial químico do metal, nas duas fases.

A taxa de extração de metal pode também ser uma função da inércia do íon metálico hidratado para substituição, isto é, para a substituição de água de hidratação por um reagente complexante. Se levarmos em conta as taxas de complexação de metais nestes termos, a taxa na qual as águas de hidratação são substituídas por outras moléculas de água deve dar alguma indicação sobre a velocidade com que a complexação com exclusão da água reagente irá ocorrer. 
Notadamente, os sistemas de extração de solventes comerciais têm taxas de extração total da ordem de não mais do que uns poucos minutos. A informação disponível em tais sistemas, e até em outros sistemas, tais como os que são utilizados em química analítica, não é muito grande (Ritcey, 2006). Por isso, e por conta dos muitos fatores que influenciam a cinética, é difícil fazer generalizações em relação a este assunto. Mas quaisquer que sejam as razões, a cinética de extração do metal é sempre um ponto importante a ser investigado em processos de extração por solvente.

\subsubsection{Transferência de massa na extração por solventes}

A taxa de transferência de massa num sistema de extração por solventes depende, basicamente, de três fatores. Da área interfacial de contato entre as duas fases, do coeficiente de transferência de massa (específico para aquela interface) e da força motriz da transferência, que neste caso é a diferença de concentração entre fases.

Durante a extração, uma das fases está dispersa na outra em forma de gotículas o que gera uma grande área de contato entre as fases e por consequência fornece grande desempenho na transferência de massa.

Devido aos intricados padrões hidrodinâmicos desse tipo de sistema, uma análise exata da taxa de transferência é muito complexa, e a literatura nessa área concentra-se em tentar identificar as variáveis que controlam o processo (Baird, Hanson, \& Lo, 1991) de forma qualitativa.

A seguir, serão descritos os principais conceitos envolvidos na transferência de massa num equilíbrio líquido-líquido e os modelos desenvolvidos na literatura cujos objetivos são explicar esse fenômeno aplicado à extração por solventes.

\subsubsection{Modelos de transferência de massa}

$\mathrm{Na}$ extração por solventes duas fases líquidas estão envolvidas, com a transferência ocorrendo através da interface, que geralmente é livre, isto é, não é limitada pela presença de uma fronteira sólida. 
Segundo o modelo de filme estagnado, duas premissas são consideradas: (1) a resistência à transferência reside nos dois filmes estagnados, um em cada lado da interface, através do qual a transferência do soluto ocorre por difusão molecular, e, (2) as fases estão em equilíbrio entre si na interface. Essas premissas levam às seguintes equações:

$$
\frac{1}{k_{o x}}=\frac{1}{k_{x}}+\frac{1}{m_{y}^{\prime} k_{y}}
$$

$E$,

$$
\frac{1}{k_{o y}}=\frac{m_{x}^{\prime}}{k_{x}}+\frac{1}{k_{y}}
$$

Em que:

$k_{o j}$ é coeficiente total de transferência de massa relativo à fase j,

$k_{j}$ é coeficiente de transferência de massa relativo na fase j

$m_{j}^{\prime}$ é uma constante obtida graficamente através da curva de equilíbrio para fase j

$x$ e $y$ são os coeficientes que representam as fases aquosa e orgânica respectivamente.

As relações obtidas mostram que a resistência total é uma função da soma das resistências de cada fase.

Utilizando-se das teorias de camada-limite, alguns pesquisadores desenvolveram modelos semi-teóricos para a transferência de massa (Baird, Hanson, \& Lo, 1991):

$$
S t_{M}=\frac{k_{x} x_{D}}{U_{x}}=\frac{h}{c_{p} \rho U}\left(\frac{c_{p} \mu}{\kappa}\right)^{2 / 3}
$$

Em que:

$S t_{M}$ é o número de Stanton para transferência de massa,

$k_{j}$ é coeficiente de transferência de massa relativo na fase j,

$X_{D}$ é o fator de corrente para a fase $\mathrm{X}$, 
$U_{j}$ é velocidade,

$h$ é o coeficiente de transferência de calor,

$c_{p}$ é a capacidade calorífica específica da fase,

$\rho$ é a densidade da fase,

$\mu$ é a viscosidade, e,

$\kappa$ é a condutividade térmica.

Tais modelos auxiliam a determinação da taxa de transferência de massa, porém, o padrão de fluxo é afetado pelo arraste entre as fases, podendo haver grandes desvios entre os coeficientes calculados e os efetivamente observados.

\subsubsection{Influência da área interfacial}

Os modelos apresentados até aqui para a taxa de transferência de massa foram expressos como um fluxo de massa normal à interface entre as fases. Porém, é interessante considerar que uma fase está dispersa na outra em forma de gotículas, o que gera uma área interfacial muito grande para um determinado volume. Neste caso, é necessário expressar o fluxo de massa em termos da seção transversal do extrator, e de um parâmetro $a$, definido como a área superficial de contato entre as fases por unidade de volume disperso.

Assim, na forma diferencial, obtém-se:

$$
d N_{1}=k_{o x} a\left(c_{x b}-c_{x}^{*}\right) d z
$$

Em que $N_{1}$ é o fluxo de massa baseado na seção transversal do contator e $z$ é a distância entre as extremidades.

A integração desta equação fornece o tamanho do contator necessário a um determinado processo. 
Apesar das dificuldades geradas pelo efeito do gradiente de tensão interfacial, muitos pesquisadores tem estudado a influência da área interfacial sobre a taxa de transferência de massa em processos de extração por solvente, principalmente, em contatores do tipo colunas de extração (Baird, Hanson, \& Lo, 1991).

\subsubsection{Influência da interface}

Nas discussões prévias a respeito da taxa de transferência de massa foi considerado que na interface se atingiu o equilíbrio e que, portanto, não há resistência a esta transferência. Este é o caso para a maioria dos sistemas físicos mais simples, entretanto, mesmo no caso de interfaces limpas (isto é, não contaminadas por filmes superficiais) pode haver lentas reações heterogêneas, levando a uma redução da taxa de transferência de massa. Por outro lado, um aumento na taxa de transferência de massa pode ser causado por turbulências espontâneas provenientes de gradientes de tensão interfacial (Baird, Hanson, \& Lo, 1991).

\subsubsection{Dispersão, continuidade de fase e coalescência}

Os aspectos físicos da extração por solvente dizem respeito, principalmente, a dispersão das duas fases na mistura, o tipo de gotículas formadas, e a coalescência. Estes processos são extremamente importantes para o dimensionamento do projeto e operação de uma planta industrial.

Termodinamicamente, é esperado que a coalescência de duas fases dispersas em um sistema binário ocorra, a fim de reduzir a energia livre de superfície associada à grande área interfacial produzida na dispersão. Esses fenômenos e seus respectivos impactos, portanto, merecem especial atenção em estudos de extração de metais por solventes.

A dispersão de um líquido em outro num sistema binário pode resultar em dois tipos extremos de dispersão, um é temporário, o que requer um tempo mínimo para a coalescência da fase dispersa, e o outro é a formação de uma emulsão estável. O primeiro pode resultar numa taxa suficientemente elevada de transferência de massa do metal da fase aquosa para a fase orgânica, enquanto o segundo paralisaria por completo a transferência de massa do sistema de extração. 
A taxa de transferência de massa através da fronteira interfacial é uma função, como já visto anteriormente, da distribuição do tamanho da gota, ou da área interfacial entre as fases. O tamanho da gota é controlado pela velocidade e tipo de agitador, além da tensão superficial e as densidades das duas fases. Assim, pode-se supor que, quanto menor o tamanho de gota (uma dispersão maior) maior a taxa de transferência de massa. Contudo, há um limite, pois aumentar o grau de dispersão resulta num aumento no tempo para a coalescência da fase dispersa. Isto pode ter um efeito considerável sobre o tamanho da área de decantação requerida, especialmente se a agitação aumentar a estabilidade da emulsão formada. Além disso, se o tamanho das gotículas de fase dispersa diminuir excessivamente, elas se comportarão mais e mais como esferas rígidas, reduzindo a transferência de massa.

A agitação das duas fases, portanto, afeta tanto a taxa de transferência de massa do metal quanto a coalescência da fase dispersa; a coalescência, por sua vez, impacta na taxa de transferência do equipamento, e também, as perdas de solvente por arraste. Até certo ponto, o tamanho da gotícula produzida ao misturar as fases resulta da competição entre os efeitos concorrentes de formação das gotículas e a coalescência. Altas taxas de transferência de massa, que geralmente são indicadas por coeficientes de extração elevada, podem justificar apenas a agitação relativamente suave no contator. $O$ inverso pode ser verdadeiro para sistemas com taxas de transferência de massa baixa. A agitação suave é geralmente o que se obtém em uma coluna de placa de peneira pulsada, assim, tal contator geralmente exige taxas de transferência de massa alta. Por outro lado, um misturadordecantador é melhor para sistemas com taxas de transferência de massa baixa, pois possui agitação muito mais elevada e grandes áreas de decantação.

Em um processo de extração por solvente uma fase é dispersa na outra, e isto determina se a continuidade da operação é do tipo aquosa ou orgânica. No primeiro caso, a fase orgânica é a fase dispersa (descontínua) e a fase aquosa é a fase coesa (contínua), e no segundo tipo ocorre o inverso. 
Pesquisadores dedicaram esforços em entender os méritos de se operar um sistema no modo aquoso ou orgânico contínuo, bem como os efeitos dessa escolha em relação à transferência de massa, coalescência, e as perdas de solvente (Coulaloglou, Gal-Or, Klinzing, Tavlarides, \& Zeitlin, 1970). Por exemplo, no caso da separação de cobalto e níquel usando placa de peneira pulsada, (Ashbrook, Lucas, \& Ritcey, 1975) determinaram que utilizar o solvente em fase contínua é o melhor modo de operação da etapa de extração, proporcionando substancial aumento na taxa de separação Co / Ni. Por outro lado, demonstraram que nas etapas de lavagem e re-extração, o ideal é que se opere em sistema de aquosa contínua.

\subsection{AGENTES EXTRATANTES UTILIZADOS NA SEPARAÇÃO CO-NI}

O extratante utilizado na separação $\mathrm{Co} / \mathrm{Ni}$ é o fator principal no processo de extração por solvente. A seleção do solvente adequado deve levar em consideração os aspectos físico-químicos do processo e especificações do produto:

- $\quad$ Produto / Processo

Em relação ao produto e o processo, deve-se estudar o solvente que melhor se adéqua à Matéria-prima tendo em vista as características do produto desejado. São fundamentais os aspectos da relação $\mathrm{Ni}$ / Co e os ânions do meio aquoso em que os metais estão presentes (sulfatos, cloretos, amoniacal, etc).

- Recuperação do Solvente

Os aspectos químicos envolvidos na recuperação do solvente como o coeficiente de equilíbrio e a seletividade entre os elementos envolvidos são fundamentais para determinar sua eficiência. A eficiência, em conjunto com aspectos de projeto como vazão requerida, necessidade de estoque de e o custo do solvente determinam sua viabilidade econômica.

- Tensão interfacial

Parâmetros relativos à transferência de massa como o tamanho da gota formada na etapa de contato e agitação das fases são igualmente importantes no dimensionamento dos equipamentos de extração (reatores, decantadores, etc), e portanto, são essenciais também do ponto de vista econômico. Impurezas e outros componentes da solução podem causar alteração na tensão interfacial e devem ser levadas em consideração na seleção do solvente. 
- $\quad$ Diferença de densidade

Este parâmetro físico deve ser analisado com muito cuidado, pois tem especial influência no processo. A diferença de densidade entre a solução aquosa e a solução orgânica influencia, principalmente, o tempo de separação entre as fases, e assim, é determinante no dimensionamento dos decantadores. A diferença de densidade tem ainda influência no arraste e perda de solução aquosa - fundamental para os custos de operação - e no rendimento da extração.

- Viscosidade

A viscosidade da solução orgânica deve ser levada em consideração, pois tem grande importância no rendimento da extração, projeto mecânico dos equipamentos e ainda, na difusão e no coeficiente de transferência de massa, fundamentais à eficiência da extração.

A tabela abaixo apresenta as principais classes e tipos de solventes utilizados nos processos de separação entre níquel e cobalto:

Tabela 3.2 - Extratantes utilizados nos processos de separação Ni / Co

\begin{tabular}{|c|c|c|}
\hline Solvente & Nomes comerciais & Observações \\
\hline Ácido Fosfórico & DEHPA & Menor Seletividade \\
\hline Ácido Fosfônico & $\begin{array}{l}\text { P204, PC88A, } \\
\text { lonquest } 801\end{array}$ & Menor Seletividade \\
\hline Ácido Fosfínico & Cyanex 272 & Maior Seletividade \\
\hline $\begin{array}{l}\text { Ácido } \\
\text { Isododecilfosfatânico }\end{array}$ & IDDPA & Menor Seletividade \\
\hline Quelante & LIX, Acorga & Utilizado em meio amoniacal \\
\hline Ácido Monocarboxílico & Versatic 10 & Extratante de $\mathrm{Ni}$ \\
\hline Amina Terciária & $\begin{array}{l}\text { Alamine } 336^{\underline{a}} \\
\text { Adogen } 363\end{array}$ & Utilizado em meio clorídrico \\
\hline Tri-Butil Fosfato & TBP & $\begin{array}{l}\text { Baixa eficiência em meio } \\
\text { sulfúrico }\end{array}$ \\
\hline
\end{tabular}

Fonte: (Ritcey, 2006)

No caso estudado, devido à constituição da matéria-prima, a lixiviação é feita em meio sulfúrico. Assim, os solventes quelantes e à base de aminas terciárias não podem ser utilizados, pois somente possuem efeito extratante em meios amoniacais e clorídricos, respectivamente. 
O solvente à base de tri-butil fosfato possui baixa eficiência em meio sulfúrico, apresentando problemas quanto a arraste e perda.

O solvente à base de ácido carboxílico é, na verdade utilizado como extratante de níquel em soluções aquosas e não de cobalto (como todos os outros da lista). Por esse motivo, para o processo em questão, este solvente é economicamente inviável. Como o cobalto, na grande maioria das refinarias está em menor quantidade na solução em relação ao níquel, é mais econômico extrair o cobalto.

Ainda segundo Ritcey, 2006, os solventes à base de ácidos alquilfosfatados possuem a seguinte ordem de seletividade:

Fosfórico < Fosfônico < Fosfínico

Baseado nestas informações, o solvente (dentre os conhecidos da literatura) que mais se adéqua ao processo estudado é o ácido fosfínico. O principal fabricante mundial deste reagente é a empresa canadense Cytec, que batizou o ácido fosfínico com o nome comercial de Cyanex 272. As principais características físico-quimica deste composto pode ser vista no Anexo A.

\subsection{MODELAGEM DE PROCESSOS DE EXTRAÇÃO POR SOLVENTE NI/CO}

Até $\mathrm{o}$ presente momento as técnicas mais utilizadas para tentar simplificar e entender o complexo comportamento de extração de metais pelo ácido fosfínico são: carregamento por $\mathrm{pH}$ ou curva $\mathrm{S}$, gráficos de $\log \mathrm{D}$ e tratamentos estatísticos de resultados empíricos como redes neurais, análise de regressão, etc. (Bourget, Sodestrom, Jakovljevic, \& Morrison, 2011). A principal dificuldade da aplicação eficiente dos métodos citados é o entendimento do comportamento do extratante em soluções multicomponentes (nas quais há a concorrência de vários metais pelo carregamento da solução de extração), além da variação das condições reais de operação dos processos. 


\subsubsection{Curvas S}

A afinidade do extratante pelos metais de interesse é tipicamente representada por um gráfico de carregamento do solvente em função do $\mathrm{pH}$. Este tipo de gráfico é chamado de curva S. Para o ácido alquil fosfínico (Cyanex 272) a curva S típica é dada abaixo:

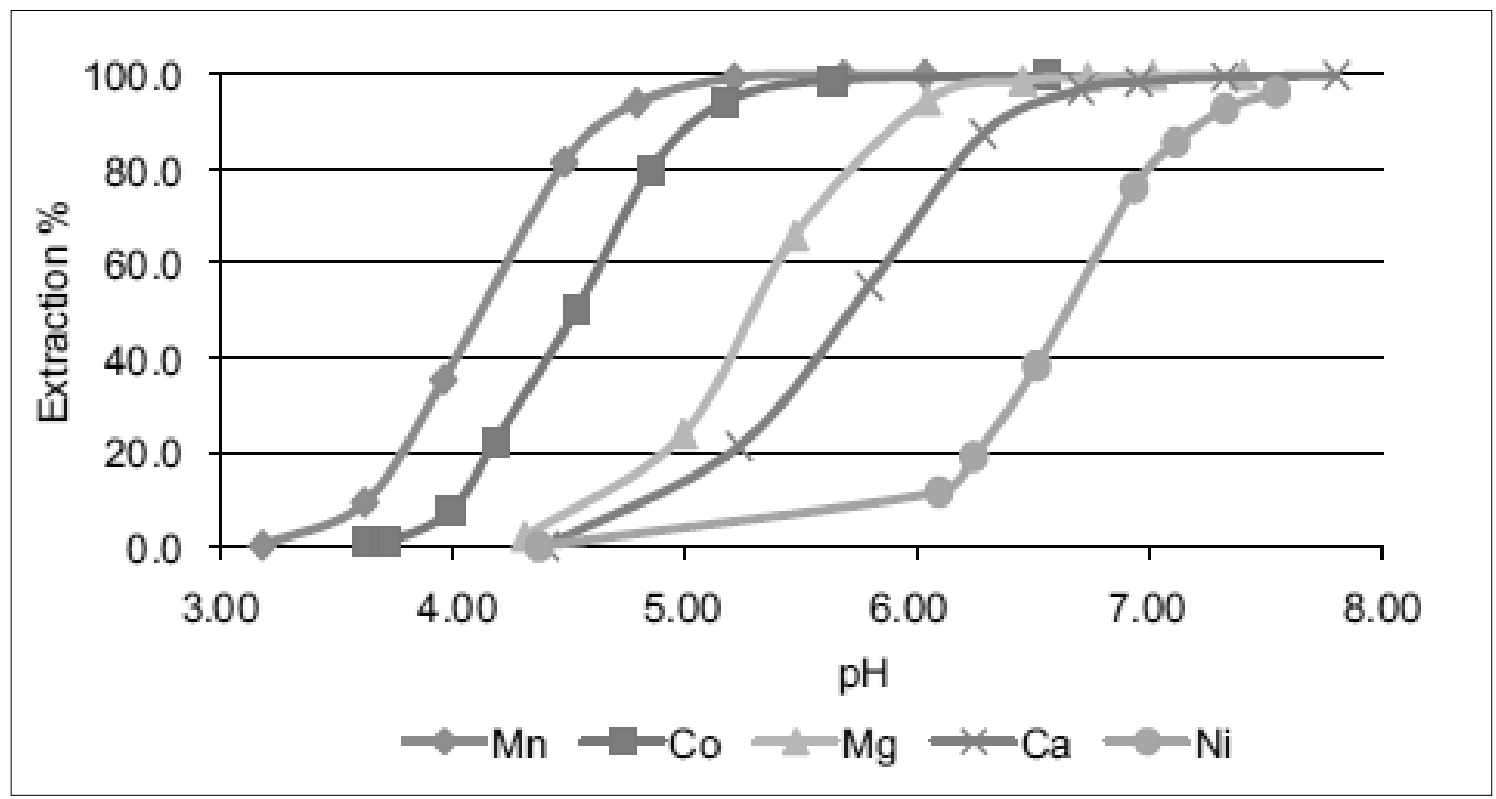

Figura 3.2 - Extração de metais pelo ácido fosfínico em função do $\mathrm{pH}$. Condições da solução: $[\mathrm{Me}]=0,001 \mathrm{M}$ (como sulfato), [ácido fosfínico] $=0,1 \mathrm{M}$, $\mathrm{O} / \mathrm{A}=1$, temperatura $=50^{\circ} \mathrm{C}$. Fonte: (Bourget, Sodestrom, Jakovljevic, \& Morrison, 2011)

A aplicação deste tipo de curva é limitada em termos de modelagem do processo. De maneira geral, curvas $S$ são geradas usando soluções de alimentação com um único metal, e, a concentração do metal é consideravelmente menor do que a capacidade de carregamento da solução orgânica. Assim, curvas $\mathbf{S}$ geradas nestas condições são apenas uma referência do comportamento e do processo de extração dos metais quando em solução multicomponente.

\subsubsection{Gráficos de $\log D$}

Gráficos de $\log D$ versus $\mathrm{pH}$ e $\log \mathrm{D}$ versus concentração de extratante (sendo $\mathrm{D}$ o coeficiente de distribuição do metal entre as fases aquosa e orgânica. $D=[\mathrm{M}]$ org / [M] aq) são igualmente comuns para a interpretação do processo de extração de metais. 
A curva de log $\mathrm{D}$ versus $\mathrm{pH}$ pode ser usada para estimar a troca de prótons no processo e curvas de log $\mathrm{D}$ versus [Extratante] podem ser utilizadas para estimar a proporção de metal na fase orgânica após a reação.

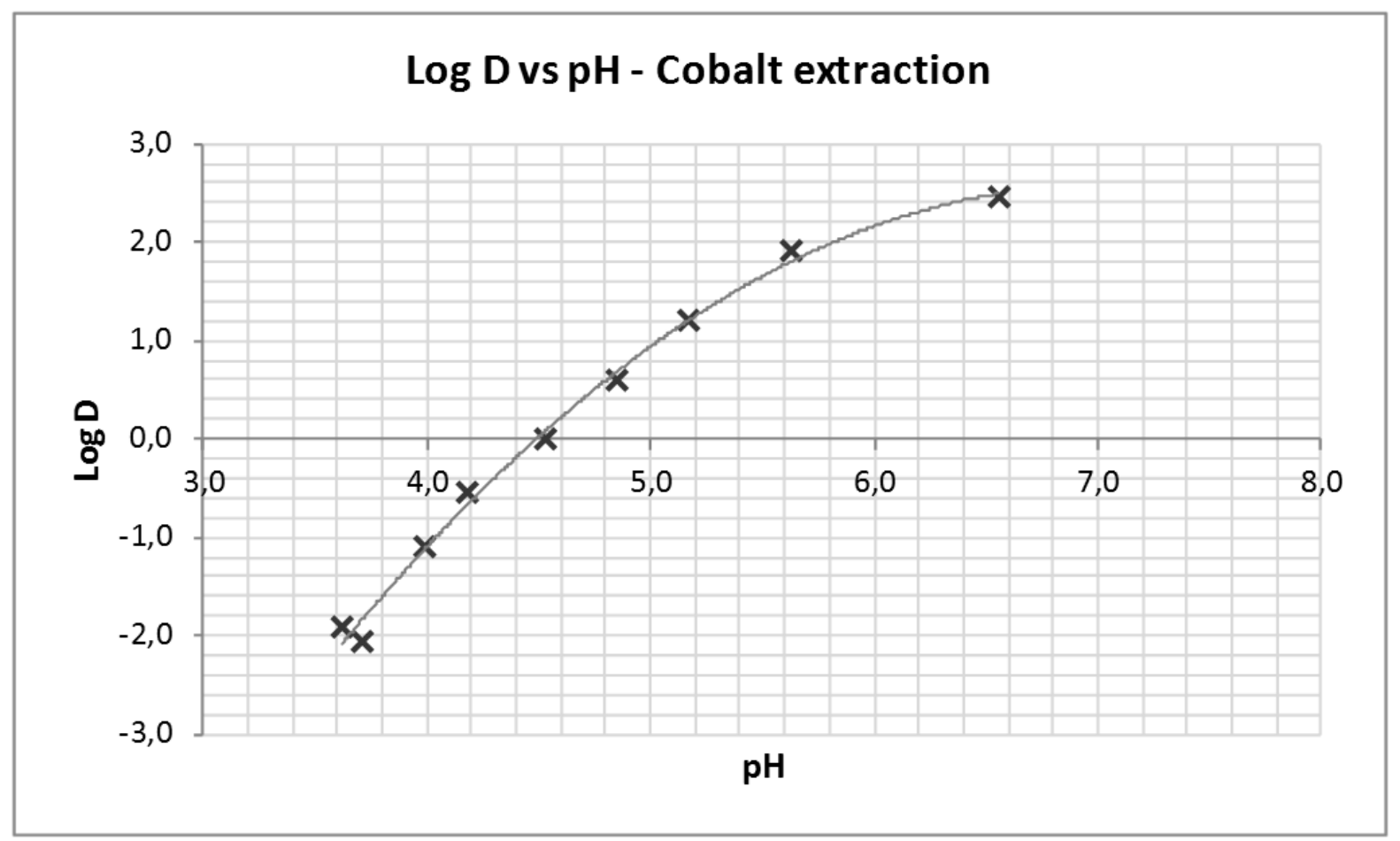

Figura 3.3 - Extração de cobalto pelo ácido fosfínico em função do $\mathrm{pH}$. Condições da solução: $[\mathrm{Co}]=0,001 \mathrm{M}$ (como sulfato), [ácido fosfínico] $=0,1 \mathrm{M}, \mathrm{O} / \mathrm{A}=1$, temperatura $=50^{\circ} \mathrm{C}$. Fonte: (Bourget, Sodestrom, Jakovljevic, \& Morrison, 2011)

Apesar de curvas de $\log \mathrm{D}$ fornecerem uma visão útil ao processo, assim como curvas $\mathrm{S}$, esses dados são aplicáveis a carregamentos baixos da solução orgânica (baixas concentrações dos metais) e limitados à alimentação de um único metal. Assim, do ponto de vista de modelagem, este tipo de curva somente por ser usada como referência.

\subsubsection{Curvas empíricas - Tratamentos estatísticos}

A separação de metais por extração é alcançada através da otimização de uma série de parâmetros que, historicamente, vem sendo estudados através de trabalhos empíricos. Devido à complexidade envolvida no comportamento deste processo, este método de modelagem tem sido o mais utilizado pelos pesquisadores. 
Os principais parâmetros que influenciam na reação de extração estão relacionados à temperatura, aromaticidade do diluente, composição da solução a extrair e, ao pH de equilíbrio da solução. Estudos conduzidos pelo fabricante do produto (Cytec Industries Inc., 2008) mostram que um modelo empírico para este comportamento seria:

$\log (S)=1,8827+0,0332 \mathrm{~T}+0,01249 \mathrm{~A}+0,0033 \mathrm{PT}-0,002151 \mathrm{PA}-0,0003405 \mathrm{~T}^{\wedge} 2$

Em que:

$\mathrm{S}=$ Razão de separação Co/Ni,

$\mathrm{T}=$ Temperatura $\left({ }^{\circ} \mathrm{C}\right)$,

$\mathrm{A}=$ Aromaticidade do diluente (\%),

$\mathrm{P}=\mathrm{pH}$ de equilíbrio,

Os testes que geraram os resultados acima foram conduzidos em fluxo contínuo, e em contracorrente. Segundo os dados dos pesquisadores, cerca de $99,5 \%$ do cobalto na solução de alimentação foi recuperado numa corrente de saída em que a razão Co-Ni foi maior do que 1000 para 1.

As condições e parâmetros dos testes são descritas na Tabela 3.3, e o fluxograma básico dos testes está demonstrado na Figura 3.4:

Tabela 3.3 - Parâmetros do teste de extração conduzidos pela Cytec

\begin{tabular}{ll}
\hline Parâmetro & Valor \\
\hline Solvente $(\mathrm{v} / \mathrm{o})$ & $20 \%$ Cyanex 272, diluente: MSB210 \\
Solução de alimentação $(\mathrm{g} / \mathrm{l})$ & $2 \mathrm{Co}, 100 \mathrm{Ni}$ como sulfatos, $\mathrm{pH} 5$ \\
Solução de lavagem $(\mathrm{g} / \mathrm{l})$ & $40 \mathrm{Co}$, como sulfato, $\mathrm{pH} 3$ \\
Temperatura & $50^{\circ} \mathrm{C}$ \\
Razão das fases & Extração A/O = 2 e Lavagem O/A = 32 \\
Tempo de residência de reação & 4 minutos \\
\hline
\end{tabular}




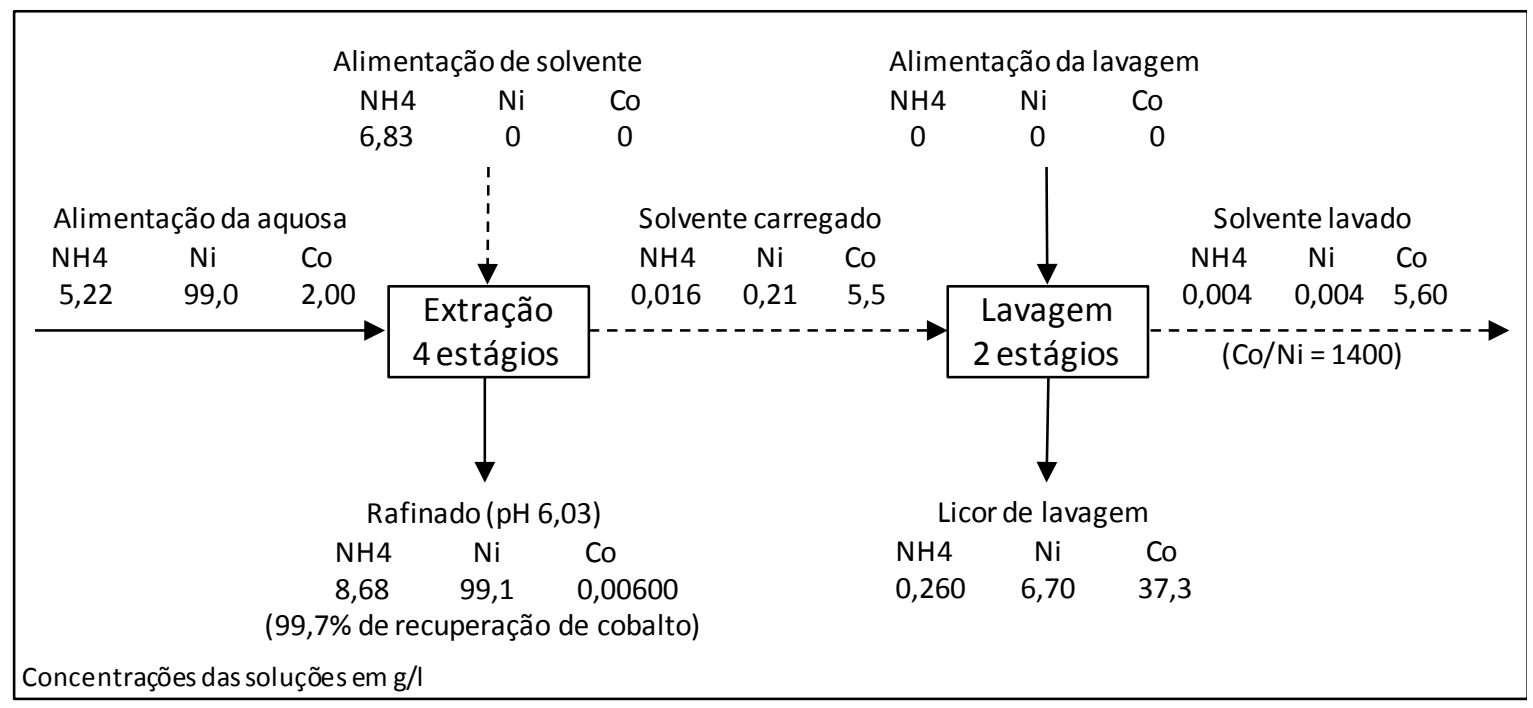

Figura 3.4 - Fluxograma básico dos testes de extração contínua conduzidos pela Cytec. Fonte: (Cytec Industries Inc., 2008)

Em tese de Mestrado, defendida pelo engenheiro Wesley Ferreira, parâmetros de $\mathrm{pH}$, temperatura e razão aquosa/orgânica foram utilizados para otimizar o processo de extração por solvente empregado na separação Ni / Co (Ferreira, 2002). Foi utilizado o método de ajuste por redes neurais para se obter a melhor combinação dos fatores.

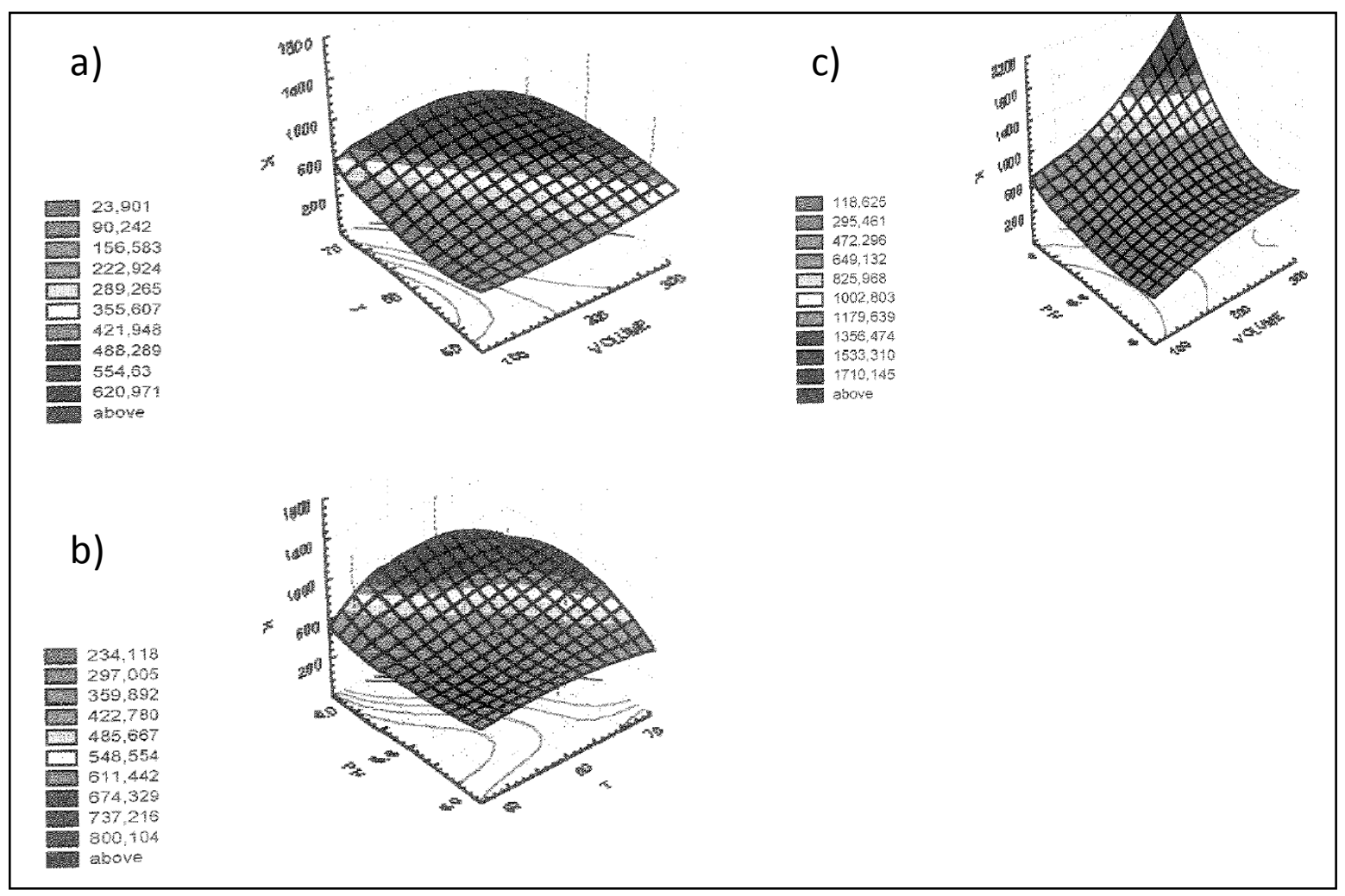

Figura 3.5 - Superfícies de resposta encontradas nos experimentos conduzidos por Ferreira. Resultados obtidos em termos de coeficiente de partição (K). Fonte: (Ferreira, 2002) 
O coeficiente de partição $(K)$ é definido como sendo a razão da concentração de cobalto na fase orgânica e a concentração de cobalto na fase aquosa. As condições de estudo foram:

a) $\mathrm{O} \mathrm{pH}$ foi mantido fixo em 5,4 e variou-se a temperatura e o volume orgânica utilizado,

b) $\mathrm{O}$ volume de orgânica foi fixado em $200 \mathrm{ml}$ enquanto variou-se $\mathrm{pH}$ e temperatura, e

c) A temperatura foi mantida fixa em $60^{\circ} \mathrm{C}$ e variou-se o volume de orgânica e o $\mathrm{pH}$ de equilíbrio

Os resultados obtidos pelos dados experimentais e com a utilização do sistema de redes neurais apontaram a região ótima de trabalho na proporção de volume de orgânica : volume de aquosa de $2: 1, \mathrm{pH}$ entre 5,4 e 5,8 e temperatura entre $60 \mathrm{e}$ $70^{\circ} \mathrm{C}$.

Em artigo apresentado por Hubli e colaboradores, em 2012, a separação Ni / Co por extração por solvente foi estudada utilizando-se o extratante OPPA (ácido octil-fenil

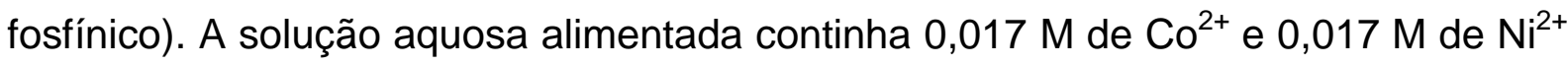
(como sulfatos). Esta solução foi colocada em contato com o solvente orgânico contendo 1,0 M de OPPA diluído em n-dodecano por 15 minutos.

Os resultados encontrados pelos pesquisadores mostraram a dependência logarítmica do coeficiente de extração (D) em relação ao $\mathrm{pH}$ de equilíbrio: 


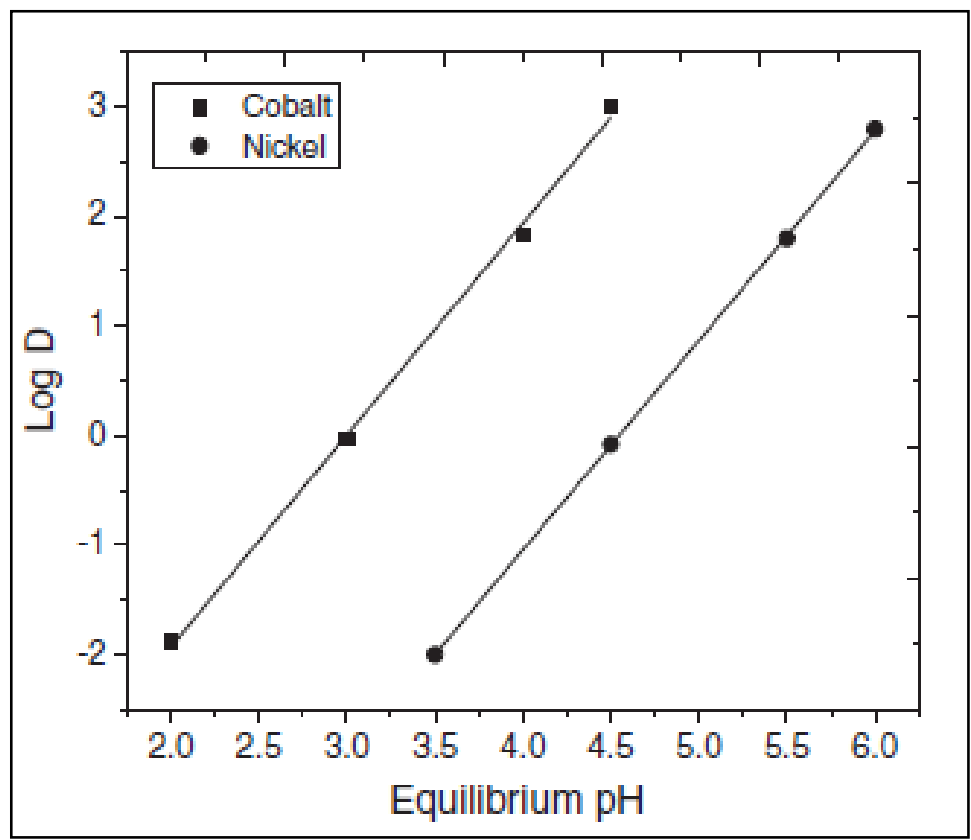

Figura 3.6 - Dependência de $\mathrm{D}$ com $\mathrm{pH}$ de equilíbrio. Fase orgânica: 1,0 OPPA, Fase aquosa: Solução de sulfato de cobalto $(0,017 \mathrm{M})$ e sulfato de níquel $(0,017 \mathrm{M}) . \mathrm{O} / \mathrm{A}=1 . \mathrm{T}=303 \mathrm{~K}$. Fonte: (Hubli, Vikas, S., N., \& Suri, 2012)

Os autores demonstraram, também, que o gráfico de $\log \mathrm{D}$ pelo $\log$ da concentração de OPPA tende a uma reta com inclinação aproximadamente 2:

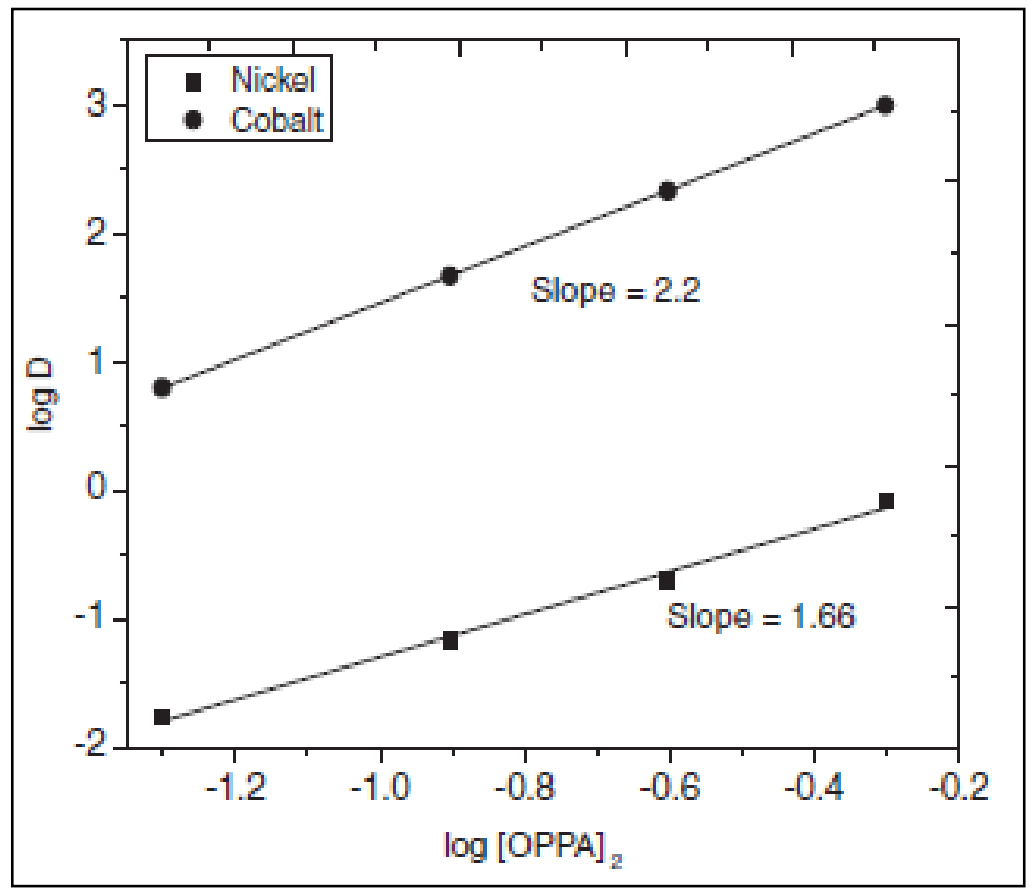

Figura 3.7 - Dependência de D com a concentração de OPPA. Fase orgânica: OPPA em n-dodecano, fase aquosa: Solução de sulfato de cobalto $(0,017 \mathrm{M})$ e sulfato de níquel $(0,017 \mathrm{M}) . \mathrm{O} / \mathrm{A}=1 . \mathrm{T}=303 \mathrm{~K}$. Fonte: (Hubli, Vikas, S., N., \& Suri, 2012) 
Os autores concluíram através do estudo apresentado, que o reagente OPPA pode ser utilizado na separação $\mathrm{Ni}$ / Co com tanta eficiência quanto o Cyanex 272, porém com eficiência máxima (fator de separação $\mathrm{Co} / \mathrm{Ni}$ de 1400) em pH de equilíbrio em 4,5. Enquanto que o Cyanex 272 alcança sua eficiência máxima (fator de separação $\mathrm{Co} / \mathrm{Ni}$ de 1400) em pH 5,2. Sendo assim, segundo os autores, o reagente OPPA pode ser utilizado com vantagem econômica em processos cujo pH de operação é mais reduzido.

Em estudo apresentado pelos pesquisadores Swain e Otu, 2011, o solvente Cyanex 272 foi utilizado como agente extratante dos elementos da série dos lantanídeos (terras raras). A percentagem extraída dos Ln foi estudada como uma função da concentração de Cyanex 272 assim como do pH de equilíbrio. Uma função nãoplanar exponencial modificada foi proposta para predizer (modelar) o fator $\mathrm{E}$ (porcentagem de extração). A equação proposta foi:

$$
E=100-A_{3} \exp ^{-[\text {Cyanex } 272]+p H}+B_{3}
$$

Em que os parâmetros $A_{3}$ e $B_{3}$ foram estimados por análise de regressão (usando algoritmo de Trust-Region) para ajustar uma superfície não-planar multivariada. Os resultados estão demonstrados na figura a seguir: 


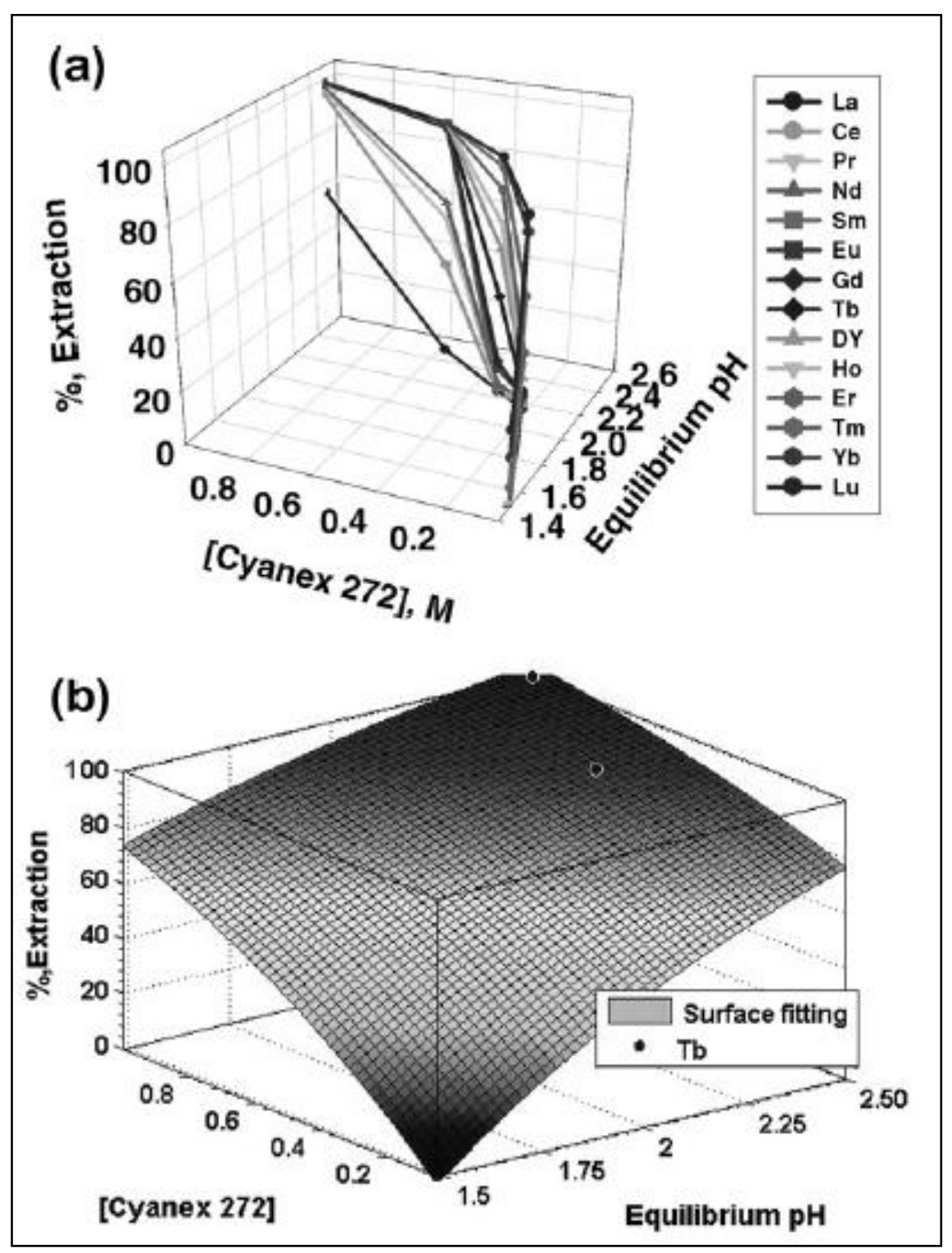

Figura 3.8 - Efeito da [Cyanex 272] e pH quando ambos sofrem variação simultaneamente na (a) percentagem de extração do Ln. (b) Ajuste do modelo para mesma situação. Condições experimentais: $0,1 \mathrm{~g} / \mathrm{l}$ de cada $\mathrm{Ln}, \mathrm{O} / \mathrm{A}=1$. Fonte: (Swain \& Otu, 2011)

Tsakiridis e Agatzini (2004) apresentaram estudo a respeito da extração simultânea e separação de $\mathrm{Co}(\mathrm{II})$ e $\mathrm{Ni}(\mathrm{II})$ de soluções de sulfato contendo manganês e magnésio. O solvente utilizado como extratante foi o ácido tio-organofosfínico (Cyanex 301) diluído em Exxol D-80. Através de estudos estatísticos e análise de experimentos, os autores determinaram os principais fatores e suas interações que impactam na extração e separação Ni / Co. Foram estudados os fatores: pH de equilíbrio, temperatura, concentração de extratante e razão orgânica / aquosa (O/A). 
Na série de experimentos conduzidos pelos pesquisadores os valores mínimos e máximos das variáveis utilizados foram:

Tabela 3.4 - Extração Ni / Co por Cyanex 301. Valores de nível mínimo e máximo dos experimentos

\begin{tabular}{lllll}
\hline Fator & Variável & Nível Mín & Nível Máx & Unidade \\
\hline A & pH de extração $(\mathrm{pH})$ & 1,5 & 2,0 & $\mathrm{pH}$ \\
$\mathrm{B}$ & Temperatura $(\mathrm{T})$ & 25 & 50 & oC \\
$\mathrm{C}$ & Concentração de extratante $(\mathrm{C})$ & 10 & 20 & $\% \mathrm{v} / \mathrm{v}$ \\
$\mathrm{D}$ & Razão O/A $(\mathrm{R})$ & $1 / 2$ & $1 / 1$ & - \\
\hline
\end{tabular}

Fonte: (Tsakiridis \& Agatzini, 2004)

Através das ferramentas estatísticas: análise de Yates e análise de variância, os autores determinaram os fatores principais e suas interações que governam a extração Ni /Co. No modelo proposto pelos autores o índice de extração pode ser descrito pela seguinte equação:

$$
Y=95,73+0,39 X_{2}+1,18 X_{3}+2,34 X_{4}+0,24 X_{1} X_{3}+0,15 X_{2} X_{3}+0,31 X_{2} X_{4}
$$

Em que $Y$ é o coeficiente de extração de cobalto, e, X1, X2, X3 e X4 são variáveis que correlacionam os fatores estudados, através das seguintes equações:

$$
X_{1}=p H-\frac{1,75}{0,25}, X_{2}=T-\frac{37,5}{12,5}, X_{3}=C-\frac{15}{5}, X_{4}=R-\frac{0,75}{0,25}
$$

Para a extração de níquel, o modelo proposto é:

$$
Y=97,60+0,3 X_{1}+1,1 X_{3}+0,5 X_{4}+0,15 X_{3} X_{4}
$$

Os autores concluíram, também, que as condições de máxima extração de Ni e Co da solução contendo manganês e magnésio são: $\mathrm{pH}=2,0, \mathrm{~T}=50^{\circ} \mathrm{C}$, concentração de extratante $=20 \%$ e $O / A=1 / 1$. 


\section{MATERIAIS E MÉTODOS}

Com o intuito de desenvolver um modelo que represente a extração de íons de cobalto por ácido alquil fosfínico, incluindo condições em que a solução aquosa seja multicomponente e a solução orgânica atinja níveis de carregamento similares àqueles utilizados industrialmente, o presente estudo será segmentado em duas grandes partes.

Na primeira parte, utilizando-se de dados experimentais presentes na literatura, será verificada a validade das premissas e conceitos envolvidos na extração por solventes e explicitados no item 3 deste texto. Será então desenvolvido um modelo que represente a taxa de extração dos metais, do qual se possa determinar, analiticamente, a constante de equilíbrio da reação de extração.

$\mathrm{Na}$ segunda parte serão realizados experimentos de extração de metais por ácido alquil fosfínico. Contudo, as condições de temperatura e espécie de diluente serão alterados em relação à primeira parte, de maneira que se aproximem às condições verificadas industrialmente. Essas alterações são necessárias para se determinar a constante de equilíbrio da reação de extração nas condições industriais.

Utilizando a mesma metodologia da primeira parte, serão determinadas as constantes de equilíbrio de extração nestas condições. As constantes de equilíbrio determinadas, então, serão usadas para desenvolver um modelo para a taxa de extração que leve em consideração a extração simultânea dos metais a partir de soluções concentradas.

Este tipo de abordagem não foi encontrado na literatura consultada e é a chave deste trabalho. Ratificando, esta abordagem consiste em desenvolver modelo para condição multicomponente e alto carregamento do extratante a partir da determinação das constantes de equilíbrio da extração de metais, verificadas, por sua vez, a partir de experimentos em condições monocomponente e de baixo carregamento do extratante. O fluxograma da Figura 4.1 demonstra como esta abordagem foi empregada: 


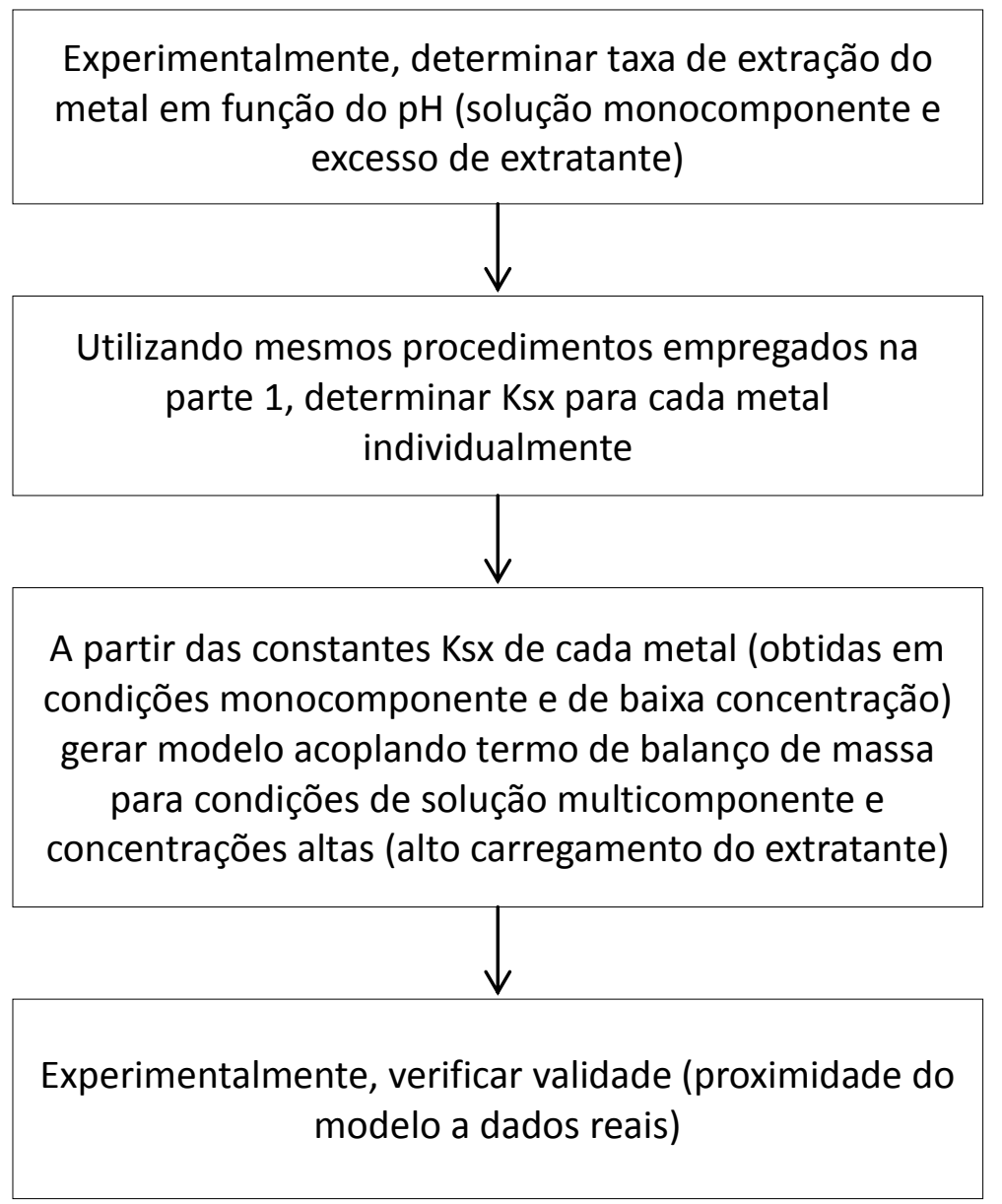

Figura 4.1 - Fluxograma da abordagem realizada para desenvolver modelo para condição multicomponente e alto carregamento do extratante.

\subsection{CONDIÇÕES EXPERIMENTAIS UTILIZADAS NA LITERATURA PARA OBTENÇÃO DOS DADOS}

Para o ajuste do modelo baseado nas equações do mecanismo da equação de extração, foram utilizados dados experimentais, gentilmente cedidos pela empresa Cytec, fabricante do Cyanex 272.

Os experimentos, segundo os dados técnicos da Cytec, foram conduzidos nas seguintes condições:

Agente extratante: Ácido fosfínico (Cyanex 272) à concentração de 0,1M,

Diluente orgânico: Combinação de isoalcanos e cicloalcanos (nome comercial: Isopar M, produzido pela empresa Exxonmobil Chemical), 
Solução Aquosa: $\quad 0,001 \mathrm{~mol} / \mathrm{L}$ dos íons metálicos de cobalto, níquel, manganês e magnésio, como sulfatos em $0,5 \mathrm{M}$ de $\mathrm{Na}_{2} \mathrm{SO}_{4}$

Condições da reação de extração:

- $\mathrm{T}=50 \stackrel{\circ}{\circ} \mathrm{C}$

- Razão volumétrica de orgânica / aquosa $(O / A)=1$

- $\mathrm{pH}$ do sistema ajustado com solução de $2,5 \mathrm{M}$ de $\mathrm{NaOH}$

As extrações foram realizadas por contato das fases aquosa e orgânica em recipientes de $100 \mathrm{ml}$ fabricados em vidro. A temperatura mantida constante através de circulação de água por camisa externa ao recipiente. As fases são mantidas em contato por 15 minutos sob agitação.

$\mathrm{O}$ pH é ajustado com adições de pequenas porções da solução de $\mathrm{NaOH}$ e o pH de final é medido após a separação de fases.

\subsection{REATOR UTILIZADO PARA OS EXPERIMENTOS}

Os experimentos empregados para o desenvolvimento do segundo modelo (que leva em consideração a solução multicomponente e alto carregamento da solução orgânica), bem como as determinações analíticas, foram realizados nas dependências do laboratório de pesquisas da empresa Votorantim Metais.

Os testes de extração foram conduzidos em reator encamisado, desenvolvido para simular as condições de agitação de reatores industriais. Um desenho esquemático desse reator pode ser visto na figura a seguir: 


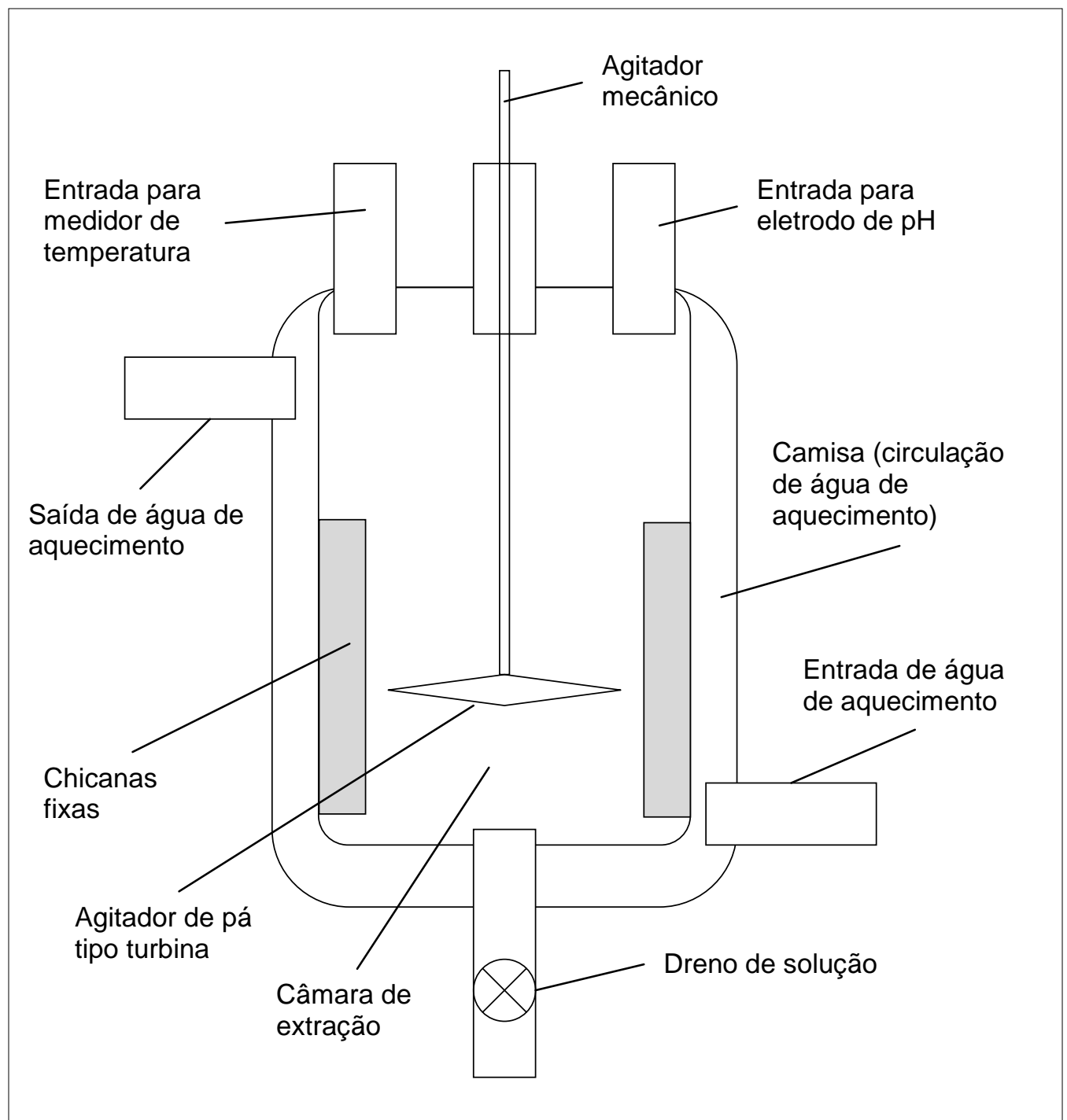

Figura 4.2 - Desenho esquemático do reator encamisado empregado nos experimentos de extração de metais por solventes

A câmara do reator tem capacidade para um litro de solução. O agitador tipo turbina de pás retas e as chicanas fixas (são quatro chicanas dispostas no entorno da parte interna da câmara de reação) geram um ambiente de mistura similar ao encontrado em equipamentos industriais do tipo reator / decantador. A rotação de agitação foi mantida em, aproximadamente, $1000 \mathrm{rpm}$.

Há ainda, como se nota no desenho, entradas para medidores de temperatura e $\mathrm{pH}$, além de uma entrada principal, por onde é introduzido o eixo do agitador e utilizada , também, para inserir os reagentes.

No fundo do reator tem-se o dispositivo de saída (tubulação mais válvula) de onde se pode fazer a retirada da solução de forma controlada, o que auxilia na remoção das fases de forma separada. 


\subsection{PARÂMETROS EXPERIMENTAIS}

Os principais parâmetros utilizados nos experimentos estão listados abaixo:

Tabela 4.1 - Parâmetros experimentais

\begin{tabular}{|c|c|}
\hline Experimento & Parâmetros \\
\hline $\begin{array}{l}\text { Cinética da reação de } \\
\text { extração de cobalto } \\
\text { (tempo para equilíbrio) }\end{array}$ & $\begin{array}{l}{[\mathrm{Co}]_{\text {aq }} \text { inicial }=0,02 \mathrm{M} \text { como sulfato }} \\
{\left[\mathrm{Na}_{2} \mathrm{SO}_{4}\right] \mathrm{aq}=2 \mathrm{M}} \\
{[\mathrm{RH}]_{\text {org }} \text { inicial }=0,6 \mathrm{M}} \\
\text { Diluente }=\text { Querosene industrial } \\
\text { Volumes }(\mathrm{A} / \mathrm{O})=0,5 \mathrm{~L} / 0,5 \mathrm{~L} \\
\text { Temperatura }=60^{\circ} \mathrm{C}\end{array}$ \\
\hline $\begin{array}{l}\text { (1)Extração de cobalto em } \\
\text { função do } \mathrm{pH}\end{array}$ & $\begin{array}{l}{[\mathrm{Co}]_{\mathrm{aq}} \text { inicial }=0,005 \mathrm{M} \text { como sulfato }} \\
{\left[\mathrm{Na}_{2} \mathrm{SO}_{4}\right] \mathrm{aq}=2 \mathrm{M}} \\
{[\mathrm{RH}]_{\text {org }} \text { inicial }=0,1 \mathrm{M}} \\
\text { Diluente }=\text { Querosene industrial }(\text { Exxol }) \\
\text { Volumes }(\mathrm{A} / \mathrm{O})=0,5 \mathrm{~L} / 0,5 \mathrm{~L} \\
\text { Temperatura }=60^{\circ} \mathrm{C} \\
\text { pH ajustado com } \mathrm{NaOH} \text { a } 2,5 \mathrm{M} \\
\text { tempo de contato de extração }=5 \text { min }\end{array}$ \\
\hline $\begin{array}{l}\text { (2)Extração de cobalto em } \\
\text { função do } \mathrm{pH}\end{array}$ & $\begin{array}{l}{[\mathrm{Co}]_{\mathrm{aq}} \text { inicial }=0,01 \mathrm{M} \text { como sulfato }} \\
\text { Outros parâmetros: idem experimento (1) }\end{array}$ \\
\hline $\begin{array}{l}\text { (3)Extração de magnésio } \\
\text { em função do } \mathrm{pH}\end{array}$ & $\begin{array}{l}{[\mathrm{Mg}]_{\mathrm{aq}} \text { inicial }=0,01 \mathrm{M} \text { como sulfato }} \\
\text { Outros parâmetros: idem experimento }(1)\end{array}$ \\
\hline $\begin{array}{l}\text { (4)Extração de manganês } \\
\text { em função do } \mathrm{pH}\end{array}$ & $\begin{array}{l}{[\mathrm{Mn}]_{\mathrm{aq}} \text { inicial }=0,01 \mathrm{M} \text { como sulfato }} \\
\text { Outros parâmetros: idem experimento }(1)\end{array}$ \\
\hline $\begin{array}{l}\text { (5)Extração de solução } \\
\text { multicomponente (para } \\
\text { comparação modelo vs } \\
\text { real) }\end{array}$ & $\begin{array}{l}{[\mathrm{Co}]_{\mathrm{aq}} \text { inicial }=0,034 \mathrm{M}} \\
{[\mathrm{Mg}]_{\mathrm{aq}} \text { inicial }=0,25 \mathrm{M}} \\
{[\mathrm{Mn}]_{\mathrm{aq}} \text { inicial }=0,0055 \mathrm{M}} \\
\text { Todos os metais como sulfatos } \\
\text { Outros parâmetros: idem experimento }(1)\end{array}$ \\
\hline
\end{tabular}


As concentrações dos metais nos experimentos 1, 2, 3 e 4 foram escolhidas de maneira que houvesse um excesso de, no mínimo, 80\% do agente extratante. Essa estratégia é necessária para que haja uma variação pequena na concentração do extratante na fase orgânica durante a extração, e assim, simplifique a determinação da constante de equilíbrio da reação (detalhamento matemático dessa premissa pode ser encontrado no item 5.1.2 deste texto). No experimento 5, as concentrações dos metais foram escolhidas de maneira a se assemelhar às condições industrias de processo.

Para as reações de extração, as fases foram colocadas em contato por cinco minutos sob agitação de 1000rpm. Para a separação das fases após a reação, o tempo utilizado foi de dez minutos.

\subsection{ANÁLISE QUÍMICA DA SOLUÇÃO}

A análise dos metais foi feita em equipamento tipo ICP-AES na solução aquosa, sendo que a concentração dos metais na fase orgânica foi determinada por balanço mássico, uma vez que eram determinadas as concentrações nas aquosas antes e após a extração.

ICP-AES é a sigla em inglês para Inductively Coupled Plasma - Atomic Emission Spectrometry, em português: Espectrometria de Emissão Atômica por Plasma Acoplado Indutivamente. Trata-se de uma técnica de análise química que utiliza fonte de excitação de plasma de argônio à alta temperatura (7.000 - $10.000 \mathrm{~K})$.

A amostra a ser determinada é introduzida, sob a forma de neblina, no centro do plasma. Produz-se assim, átomos excitados que emitem radiação em comprimentos de ondas característicos dos elementos nela presentes. As radiações emitidas, após conveniente separação de seus comprimentos de onda por sistemas ópticos, têm suas intensidades medidas por meios de detectores de radiação específicos. A determinação da concentração é feita comparando-se essa intensidade com as concentrações correspondentes de curvas de calibração, obtidas pela medição prévia de padrões certificados de referência.

Esse tipo de equipamento é amplamente utilizado para a detecção de metais em soluções aquosas e possuem ótima precisão para largas faixas de concentração, e limites de detecção na ordem de $10 \mu \mathrm{g} / \mathrm{l}$ para os metais estudados. 


\section{RESULTADOS E DISCUSSÃO}

\subsection{DESENVOLVIMENTO DO PRIMEIRO MODELO}

Nesta primeira parte, utilizando-se dos dados experimentais presentes na literatura, será verificada a validade das premissas levantadas no item 3.2. O intuito é desenvolver um modelo que represente a taxa de extração dos metais em função do $\mathrm{pH}$ e, determinar, as constantes de equilíbrio das reações de extração para cada metal estudado.

\subsubsection{Gráficos da taxa de extração e log $D$ (dados da literatura)}

Com os dados obtidos para extração dos metais é possível traçar o gráfico da taxa de extração,E, bem como o gráfico do logaritmo do coeficiente de distribuição, $D$, em função do $\mathrm{pH}$ da solução aquosa (o coeficiente $\mathrm{D}$ representa a razão entre a concentração do metal na fase orgânica e a concentração do metal na fase aquosa após a extração):

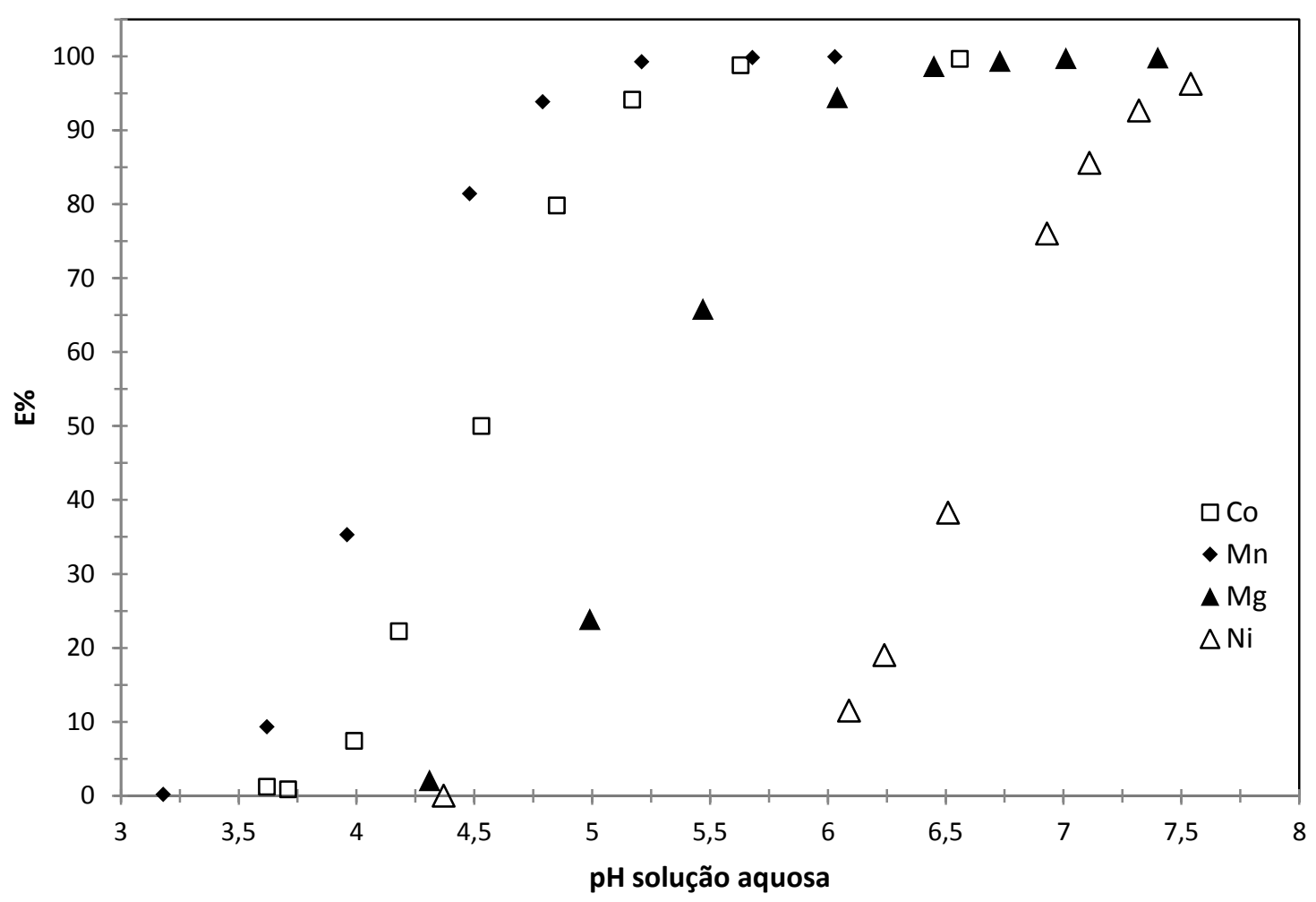

Figura 5.1 - Gráfico da taxa de extração em função do pH final da solução aquosa. Condições experimentais: Temperatura $=50^{\circ} \mathrm{C}$, concentração dos metais na solução aquosa inicial=0,001M, solução extratante $0,1 \mathrm{M}$ de Cyanex em isopar, $\mathrm{O} / \mathrm{A}=1 / 1$. 
Nota-se que o comportamento observado na extração dos metais obedece às expectativas mencionadas na teoria e se assemelha aos gráficos de outros reagentes ácidos empregados na extração de metais. O gráfico acima, também chamado de curva $\mathrm{S}$, mostra que nas condições estudadas, a extração dos metais segue a seguinte ordem: $\mathrm{Mn}, \mathrm{Co}, \mathrm{Mg}$ e $\mathrm{Ni}$.

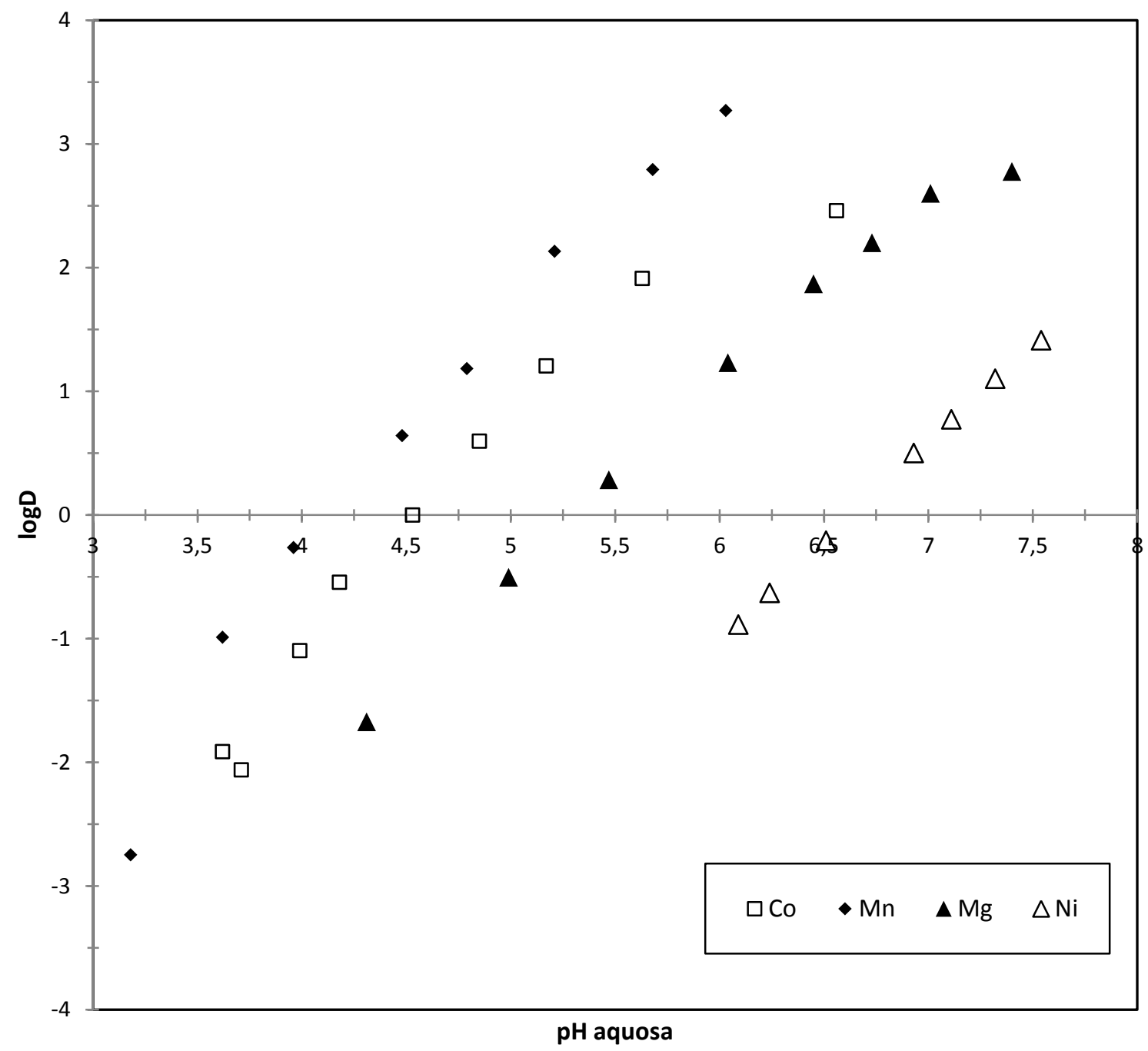

Figura 5.2 - Gráfico do logaritmo de D em função do pH final da solução aquosa. Condições experimentais: Temperatura $=50^{\circ} \mathrm{C}$, concentração dos metais na solução aquosa inicial=0,001M, solução extratante $0,1 \mathrm{M}$ de ácido fosfínico em isopar, $\mathrm{O} / \mathrm{A}=$ $1 / 1$.

Esperava-se que o comportamento da curva de $\log \mathrm{D}$ em função do $\mathrm{pH}$ fosse linear. Para boa parte dos dados, aparentemente, o comportamento é linear, porém, nos extremos da curva, principalmente, para os valores mais altos de $D$, as curvas tendem a um máximo, desviando-se da reta formada pelos pontos antecedentes. 
Este fenômeno pode ser explicado observando que $K s x$ depende da disponibilidade do complexo $M R n$. Nos casos em que a taxa de extração se aproxima de $100 \%$ (valores altos de D) a disponibilidade do complexo $M R n$ formado na fase aquosa tende a diminuir drasticamente, criando uma assíntota para KsX.

Tendo em vista esse fenômeno, para as discussões a seguir, os dados obtidos para altos valores de D serão removidos. Contudo, entende-se que a essência dessas análises não será prejudicada com esta consideração. Quando pertinente esses dados serão considerados.

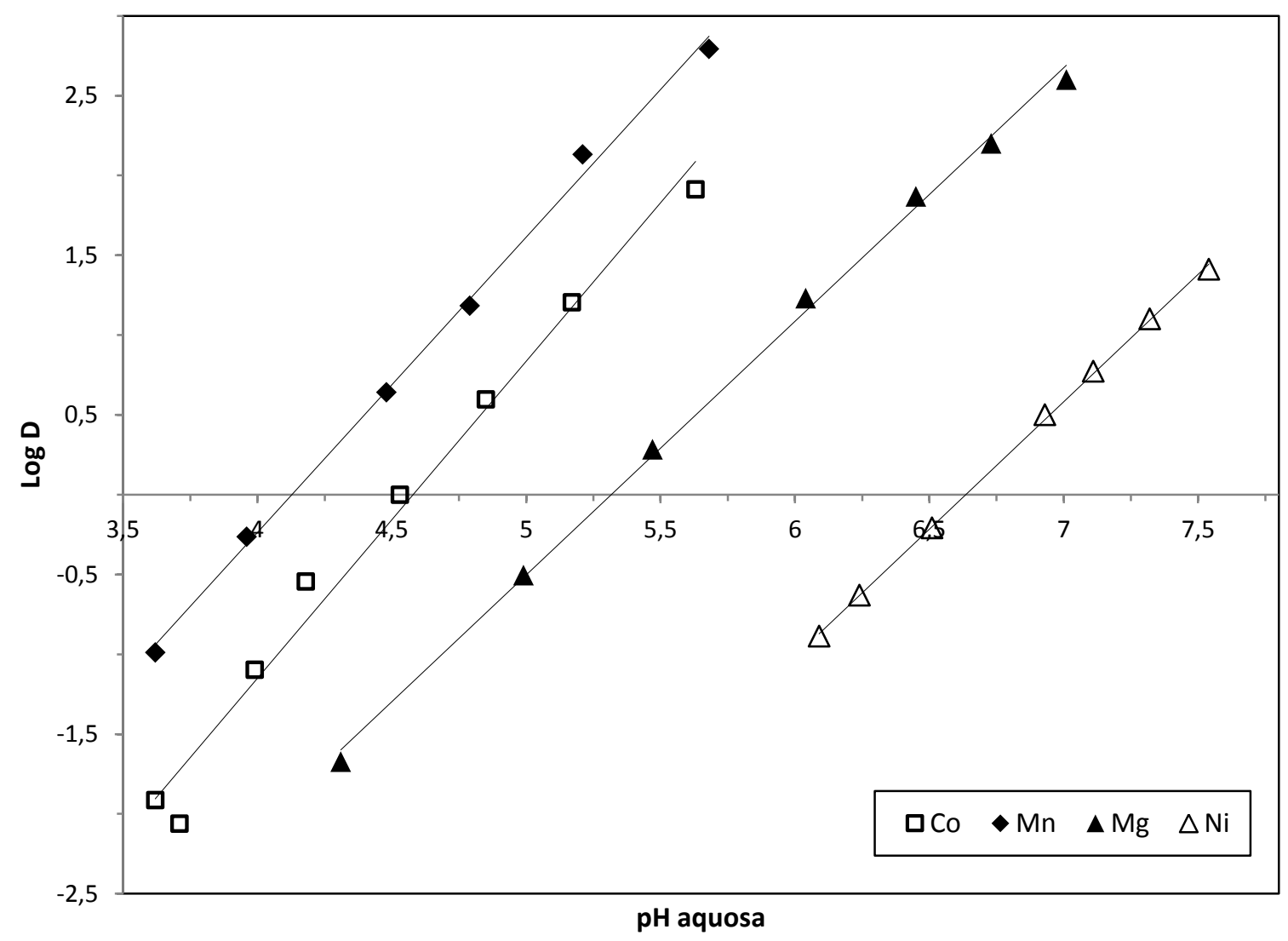

Figura 5.3 - Gráfico do logaritmo de D em função do pH final da solução aquosa. (removendo valores extremos de D). Condições experimentais: Temperatura $=50^{\circ} \mathrm{C}$, concentração dos metais na solução aquosa inicial $=0,001 \mathrm{M}$, solução extratante $0,1 \mathrm{M}$ de ácido fosfínico em isopar, $\mathrm{O} / \mathrm{A}=1 / 1$.

A curva de ajuste aos dados foi obtida por regressão linear. Os parâmetros da reta para cada metal são: 
Tabela 5.1 - Parâmetros das retas de ajuste para o gráfico de $\log \mathrm{D}$ vs $\mathrm{pH}$ para os metais extraídos

\begin{tabular}{llll}
\hline Metal & Coeficiente angular & Coeficiente linear & $\mathrm{R}^{2}$ \\
\hline Cobalto & 1,99 & $-9,10$ & $98,5 \%$ \\
Níquel & 1,60 & $-10,60$ & $99,9 \%$ \\
Magnésio & 1,59 & $-8,44$ & $99,8 \%$ \\
Manganês & 1,85 & $-7,65$ & $99,7 \%$ \\
\hline
\end{tabular}

Os valores de $R^{2}$ encontrados demonstram que os gráficos de $\log \mathrm{D}$ em função do $\mathrm{pH}$ de extração se aproximam de uma reta. Este resultado coincide com o esperado pela teoria e mencionado no item 3.2, validando assim, os conceitos desenvolvidos anteriormente para este tipo de sistema.

\subsubsection{Proposta de modelo para a taxa de extração de metais (dados da literatura)}

Retomando a equação (3.):

$$
\log D=\log K s x+m \log [R H]_{\text {org }}+n p H
$$

Todos os metais estudados neste caso são bivalentes, assim, o parâmetro $n$ é igual a dois.

Para os metais considerados, e ácido alquil fosfínico como agente extratante, o fator $m$ é igual 2 (Ritcey, 2006). Uma exceção conhecida é o níquel, cuja extração em altas concentrações possui fator $m$ é igual 3. Contudo, para esse caso estudado, em que a concentração do níquel pode ser considerada baixa (relação estequiométrica com o solvente inferior a 1\%) será considerado o fator $m$, para o níquel, também igual a 2 .

A concentração do agente extratante na fase orgânica será considerada constante nos experimentos. Esta consideração é bastante razoável, uma vez que, estequiometricamente falando, apenas $2 \%$ do extratante é consumido no caso de todo o metal ser extraído. Por fim, para este modelo, será feita a suposição de que o fator Ksx também é constante (dentro da faixa de valores de D considerada). Assim, a equação (3.) pode ser reescrita da seguinte forma: 


$$
\log D=A_{1}+2 p H
$$

Em que o parâmetro $A_{1}$ é constante e vale:

$$
A_{1}=\log K s x+m \log [R H]_{\text {org }}
$$

O ajuste do modelo consiste em determinar o parâmetro $A_{1}$ de modo que seja minimizado o erro entre o coeficiente $D$ calculado através da equação (5.2) e o coeficiente D experimental.

A função erro "e" a ser minimizada é:

$$
e=\mid \log D \exp -\log \text { Dcalc } \mid
$$

Em que os coeficientes exp e calc referem-se aos valores obtidos através dos dados experimentais e calculados, respectivamente.

Abaixo, seguem os gráficos das funções erro para os metais cuja extração se está estudando:

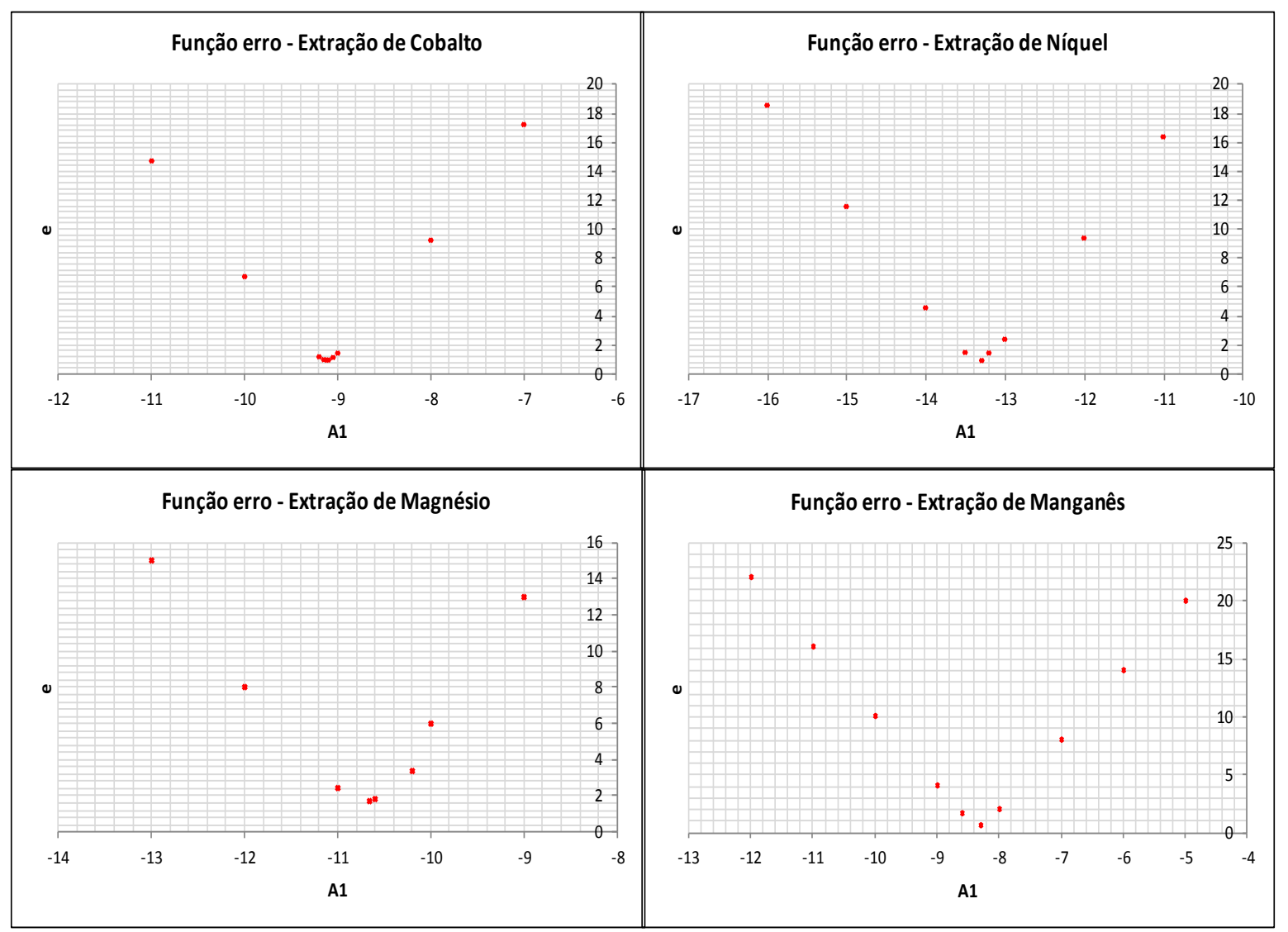

Figura 5.4 - Gráficos das funções erro: Ajuste do parâmetro $A_{1}$ relativo à extração dos metais por ácido fosfínico 
A determinação do parâmetro $A_{1}$ que minimiza a função erro para cada metal estudado fornece:

Tabela 5.2 - Determinação do parâmetro $A_{1}$

\begin{tabular}{ccc}
\hline Metal & $A_{1}$ & $e$ \\
\hline Cobalto & $-9,12$ & 0,977 \\
Níquel & $-13,29$ & 0,943 \\
Magnésio & $-10,66$ & 1,707 \\
Manganês & $-8,30$ & 0,582 \\
\hline
\end{tabular}

Tem-se, portanto para cada metal estudado os seguintes modelos para D:

- Cobalto:

$$
\log D=-9,12+2 p H
$$

- Níquel:

$$
\log D=-13,29+2 p H
$$

- Magnésio:

$$
\log D=-10,66+2 p H
$$

- Manganês:

$$
\log D=-8,30+2 p H
$$

A partir do modelo proposto para $D$, é possível determinar um modelo para a taxa de extração $E$, para cada metal estudado, uma vez que pela dedução da equação (3.), e considerando que neste caso Vorg = Vaq:

$$
E=\frac{D}{1+D} \times 100
$$

No gráfico abaixo estão projetadas as curvas calculadas (modelo) para a taxa $\mathrm{E}$, bem como, a curva dos valores experimentais: 




Figura 5.5 - Gráfico do modelo proposto para a taxa de extração $\mathrm{E}(\%)$ para os metais estudados (linhas contínuas). Os pontos identificados referem-se aos valores experimentais da taxa de extração $\mathrm{E}(\%)$ em função do $\mathrm{pH}$ final da solução aquosa. Condições: Temperatura $=50^{\circ} \mathrm{C}$, concentração dos metais na solução aquosa inicial=0,001M, solução extratante $0,1 \mathrm{M}$ de Cyanex em isopar, $\mathrm{O} / \mathrm{A}=1 / 1$.

É possível notar, pela análise do gráfico acima, que o modelo proposto para a extração dos metais pelo ácido fosfínico se ajusta adequadamente aos valores experimentais, validando para este caso os conceitos e premissas descritos na seção teórica.

\subsubsection{Determinação do valor de $K s x$ (dados da literatura)}

Retomando a equação (5.2):

$$
A_{1}=\log K s x+m \log [R H]_{\text {org }}
$$

O rearranjo da equação acima permite determinar o valor da constante da equação de extração Ksx: 


$$
K s x=10^{A 1-m \log [R H]_{\text {org }}}
$$

Para tal, a concentração do extratante na fase orgânica será considerada constante e igual a $0,1 \mathrm{M}$. Utilizando os valores de $\mathrm{A}_{1}$ determinados pelo modelo, para cada um dos metais, e fator $m$ igual a 2 , tem-se:

Tabela 5.3 - Determinação do parâmetro Ksx para os metais em estudo

\begin{tabular}{ccc}
\hline Metal & $A_{1}$ & $K s x$ \\
\hline Cobalto & $-9,12$ & $7,586.10^{\wedge}-8$ \\
Níquel & $-13,29$ & $5,129.10^{\wedge}-12$ \\
Magnésio & $-10,66$ & $2,188.10^{\wedge}-9$ \\
Manganês & $-8,30$ & $5,012.10^{\wedge}-7$ \\
\hline
\end{tabular}

5.2 DESENVOLVIMENTO DO MODELO DE EXTRAÇÃO PARA SOLUÇÕES MULTICOMPONENTES

\subsubsection{Verificação da cinética da reação}

O objetivo central deste primeiro experimento é determinar o tempo necessário para que a reação de extração alcance o equilíbrio:

Tabela 5.4 - Dados obtidos no teste de cinética para a extração de cobalto pelo ácido fosfínico

\begin{tabular}{ccc}
$\begin{array}{c}\text { Tempo } \\
(\mathrm{min})\end{array}$ & $\begin{array}{c}{\left[\mathrm{Co}^{2+}\right] \text { org }} \\
(\mathrm{M})\end{array}$ & $\begin{array}{c}{\left[\mathrm{Co}^{2+}\right] \text { org }} \\
(\mathrm{M})-\text { Réplica }\end{array}$ \\
\hline 0 & 0 & 0 \\
0,17 & 0,005057 & 0,005464 \\
0,33 & 0,00974 & 0,010232 \\
0,5 & 0,015238 & 0,015306 \\
1 & 0,014967 & 0,015188 \\
1,5 & 0,015018 & 0,014984 \\
2 & 0,014865 & 0,015306 \\
2,5 & 0,014848 & 0,015001 \\
3 & 0,014814 & 0,015069 \\
4 & 0,015001 & 0,014933 \\
5 & 0,014882 & 0,015154 \\
6 & 0,014763 & 0,014865 \\
15 & 0,014712 & 0,014814 \\
\hline
\end{tabular}


O experimento foi realizado em duplicata. Observa-se claramente na Figura 5.6 que a reação, nestas condições de temperatura e agitação, atinge seu máximo em, aproximadamente, 30 segundos. Notadamente, não é uma reação instantânea, todavia, considerando as dificuldades relativas às reações interfaciais, pode-se considerar que esta reação acontece de forma rápida, assim como previsto na literatura e exposto no item 3.2.3 deste texto.

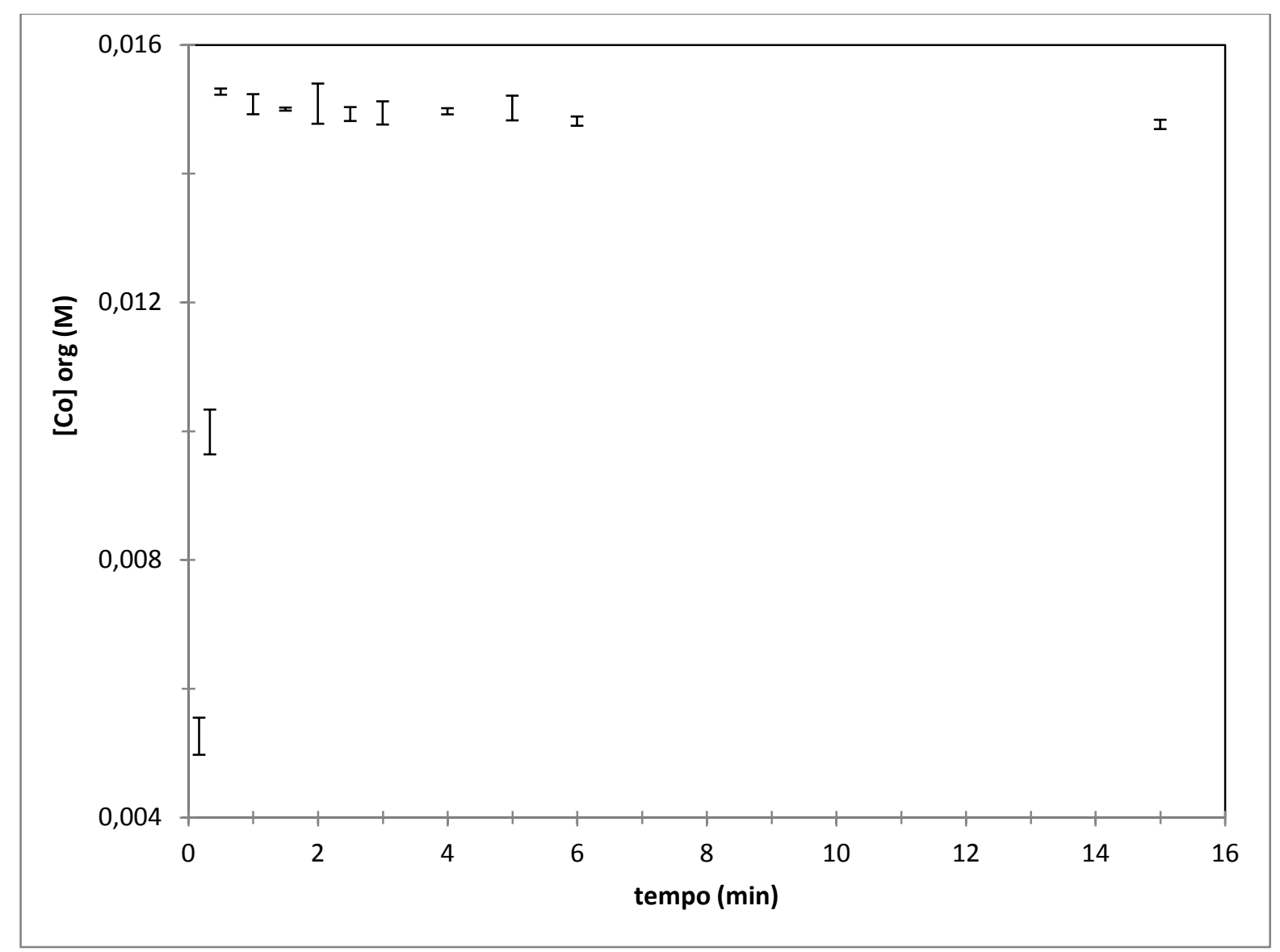

Figura 5.6 - Determinação do tempo necessário para alcançar o equilíbrio da reação de extração de cobalto

Outro ponto importante a ser ressaltado é que o tempo escolhido para o contato das reações de extração (experimentos dos itens subsequentes), de cinco minutos, é bastante adequado para que se alcance o equilíbrio da reação, e portanto, não deve interferir nos resultados. 


\subsubsection{Determinação da taxa de extração e gráfico de log $D$}

Com os dados obtidos nos experimentos para extração dos metais (Tabela) é possível traçar o gráfico da taxa de extração, E, bem como o gráfico do logaritmo do coeficiente de distribuição, D. Procedimento semelhante ao que foi adotado no item 5.1.1:

Tabela 5.5 - Dados obtidos nos experimentos de extração com ácido fosfínico dos íons cobalto, magnésio e manganês

\begin{tabular}{ccccccccc}
\hline \multicolumn{2}{c}{ Cobalto $(0,01 \mathrm{M})$} & \multicolumn{2}{c}{ Cobalto $(0,005 \mathrm{M})$} & \multicolumn{2}{c}{ Magnésio $(0,01 \mathrm{M})$} & \multicolumn{2}{c}{ Manganês $(0,01 \mathrm{M})$} \\
$\mathrm{pH}$ & {$\left[\mathrm{Co}^{2+}\right] \mathrm{aq}(\mathrm{M})$} & $\mathrm{pH}$ & {$\left[\mathrm{Co}^{2+}\right] \mathrm{aq}(\mathrm{M})$} & $\mathrm{pH}$ & {$\left[\mathrm{Mg}^{2+}\right] \mathrm{aq}(\mathrm{M})$} & $\mathrm{pH}$ & {$\left[\mathrm{Mn}^{2+}\right] \mathrm{aq}(\mathrm{M})$} \\
\hline 2,05 & 502 & 2,01 & 264 & 2,03 & 240 & 3,18 & 565 \\
2,99 & 495 & 3,01 & 261 & 3 & 242 & 3,62 & 511 \\
4,01 & 488 & 4,02 & 258 & 4,04 & 235 & 3,96 & 351 \\
4,52 & 353 & 4,51 & 187 & 4,52 & 230 & 4,48 & 118 \\
5,03 & 124 & 4,9 & 83 & 4,91 & 228 & 4,79 & 30 \\
5,12 & 92 & 5 & 59 & 5,01 & 214 & 5,21 & 3 \\
5,23 & 63 & 5,11 & 43 & 5,11 & 210 & 5,68 & 1 \\
5,53 & 18 & 5,23 & 24 & 5,21 & 171 & 6,03 & 0 \\
6,04 & 3 & 5,52 & 14 & 5,52 & 94 & & \\
& & 6,05 & 2 & 6,04 & 18 & & \\
\hline
\end{tabular}

Abaixo é possível observar o equipamento reator utilizado nos testes de extração, bem como a evolução da coloração das soluções aquosa e orgânica conforme a alteração do pH do sistema. 


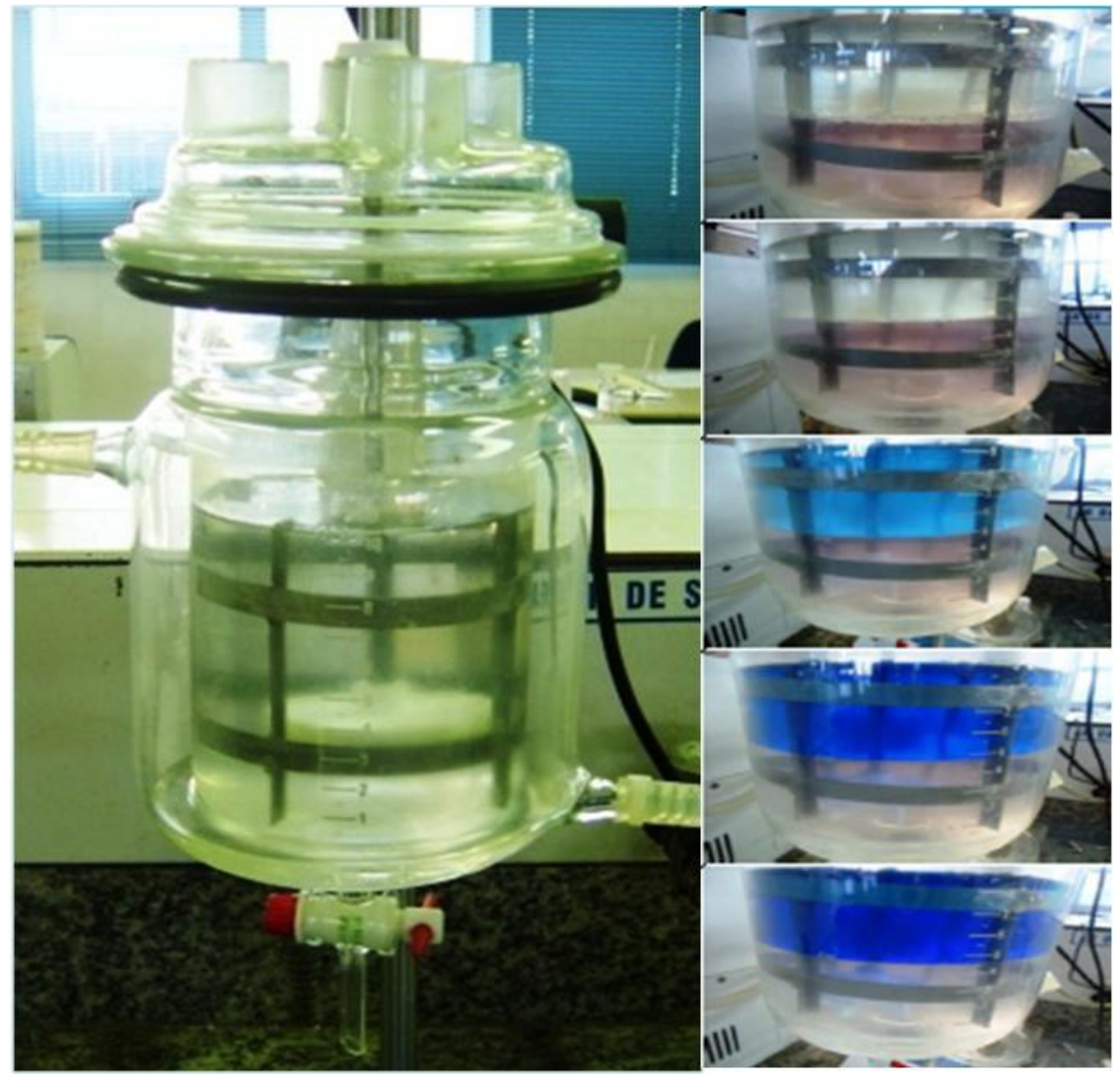

Figura 5.7 - Equipamento reator utilizado nos experimentos de extração dos metais pelo ácido fosfínico. Nas figuras laterais observa-se a extração de íons de cobalto em diferentes pHs. Conforme o aumento do pH (de cima para baixo) nota-se a redução da coloração rósea da solução aquosa (inferior) característica da presença de $\mathrm{Co}^{2+}$ e o aumento da coloração azulada da solução orgânica (superior) característica da presença do complexo $\mathrm{R}_{2} \mathrm{Co}$ 


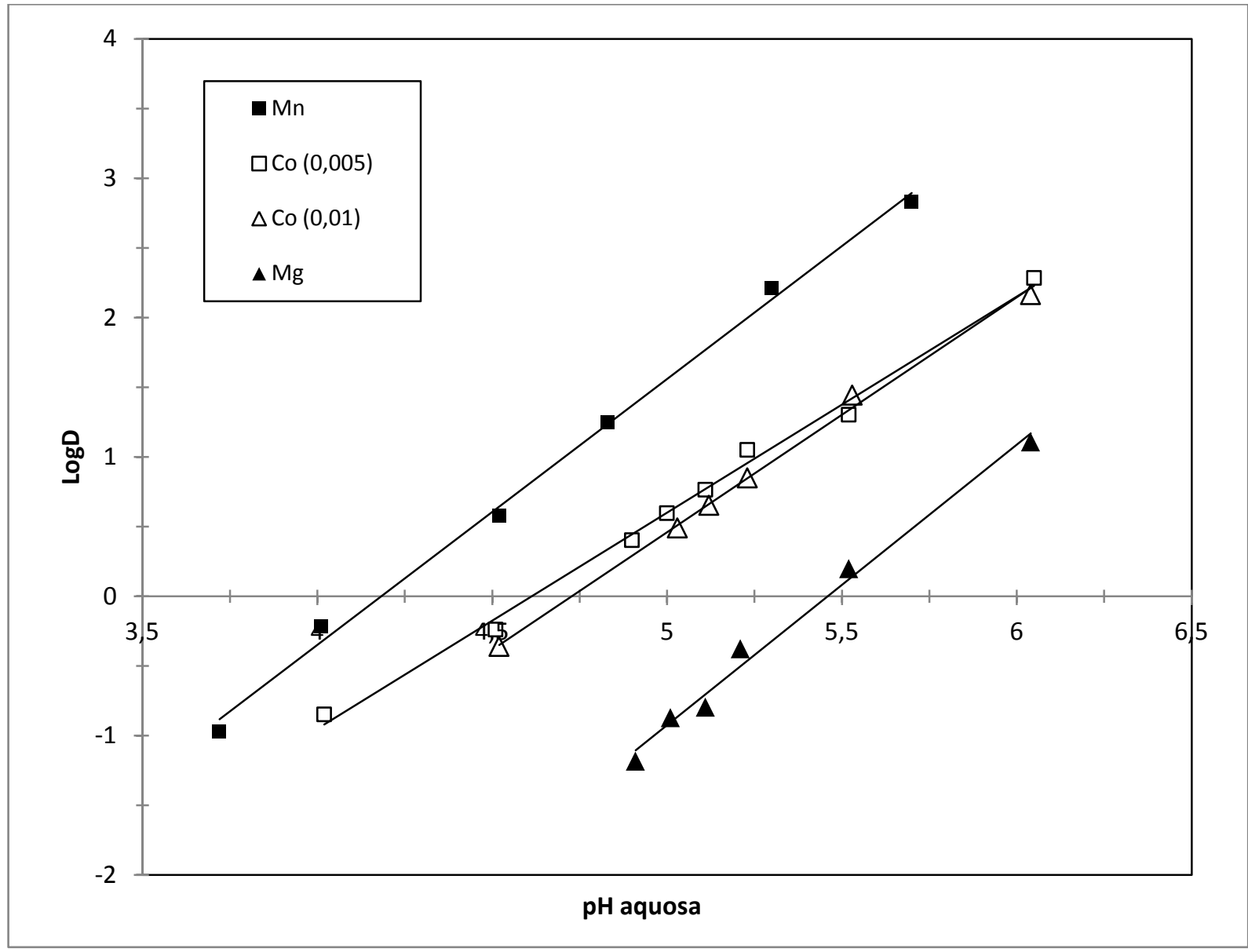

Figura 5.8 - Gráfico do logaritmo de D em função do pH final da solução aquosa.. Condições experimentais: Temperatura $=60^{\circ} \mathrm{C}$, solução extratante $0,1 \mathrm{M}$ de ácido fosfínico em exxol, $\mathrm{O} / \mathrm{A}=1 / 1$.

A curva de ajuste aos dados foi obtida por regressão linear. Os parâmetros da reta para cada experimento são:

Tabela 5.6 - Parâmetros das retas de ajuste para o gráfico de $\log \mathrm{D}$ vs pH para os metais extraídos

\begin{tabular}{lccc}
\hline Metal & Coeficiente angular & Coeficiente linear & $\mathrm{R}^{2}$ \\
\hline Cobalto $(0,005 \mathrm{M})$ & 1,5506 & $-7,1538$ & $99,44 \%$ \\
Cobalto $(0,01 \mathrm{M})$ & 1,6863 & $-7,9707$ & $99,70 \%$ \\
Magnésio & 2,0112 & $-10,979$ & $98,86 \%$ \\
Manganês & 1,9074 & $-7,9786$ & $99,66 \%$ \\
\hline
\end{tabular}


Os valores de $\mathrm{R}^{2}$ encontrados demonstram que os gráficos de $\log \mathrm{D}$ em função do $\mathrm{pH}$ de extração se aproximam de uma reta para a faixa de $\mathrm{pH}$ considerada. Estes resultados demonstram que os experimentos realizados respeitam as premissas e conceitos necessários para se obter o parâmetro Ksx para cada componente e desenvolver um modelo para a taxa de extração.

\subsubsection{Proposta de modelo para a taxa de extração de metais (dados experimentais) considerando solução monocomponente}

Utilizando do mesmo método desenvolvido no item 5.1.2, minimizando a função erro para o logaritmo de D (dados obtidos nas condições experimentais), tem-se o seguinte resultado para o ajuste do parâmetro $A_{1}$ :

Tabela 5.7 - Determinação do parâmetro $\mathrm{A}_{1}$

\begin{tabular}{ccc}
\hline Metal & $A_{1}$ & $e$ \\
\hline Cobalto $(0,005)$ & $-9,4063$ & 1,4691 \\
Cobalto $(0,01)$ & $-9,5868$ & 0,74116 \\
Magnésio & $-9,7336$ & 0,36880 \\
Manganês & $-8,4098$ & 0,40890 \\
\hline
\end{tabular}

A taxa de extração, então, considerando o parâmetro calculado, fica: 


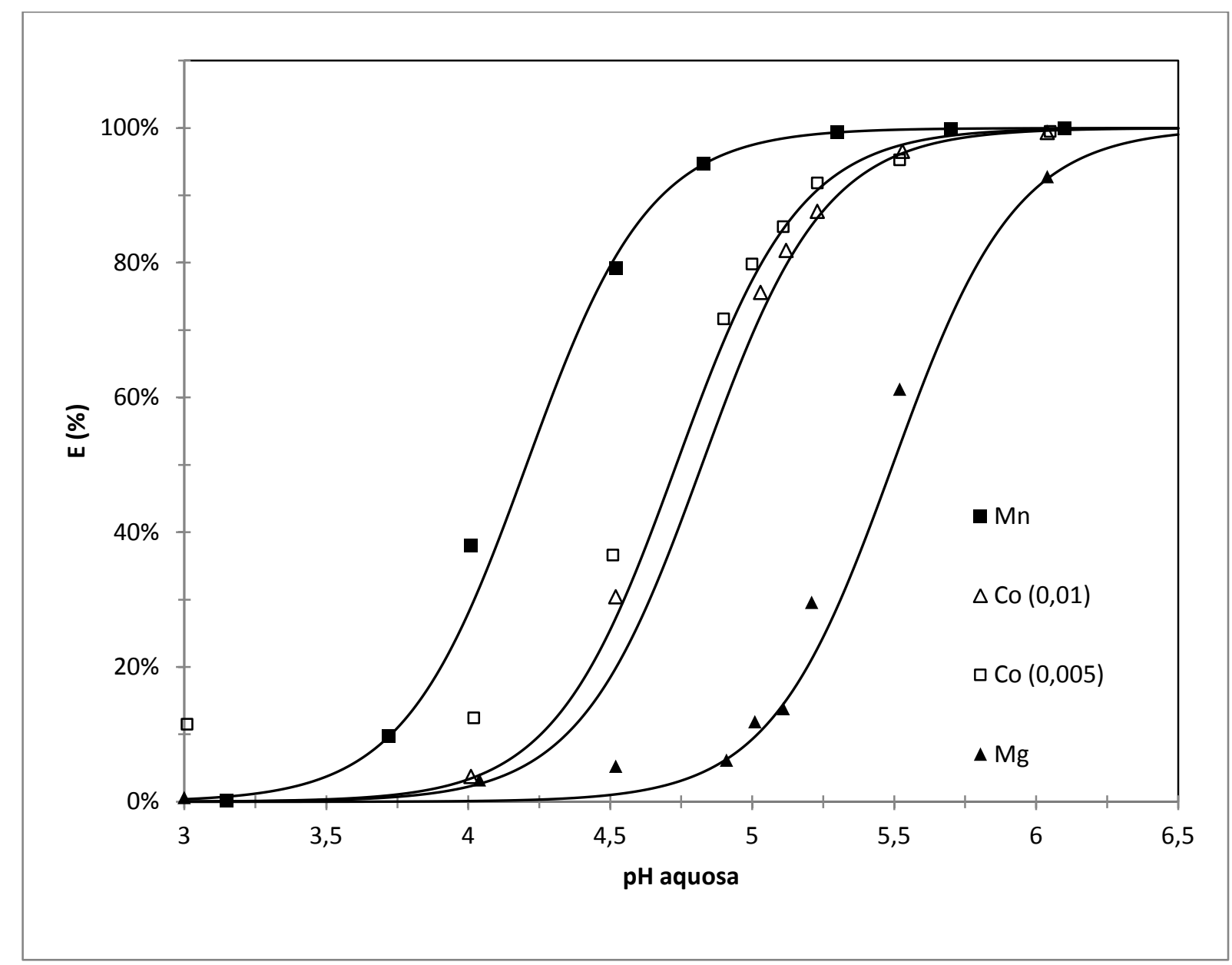

Figura 5.9 - Gráfico do modelo proposto para a taxa de extração $E(\%)$ para os metais estudados (linhas contínuas). Os pontos identificados referem-se aos valores experimentais da taxa de extração $E(\%)$ em função do $\mathrm{pH}$ final da solução aquosa. Dados obtidos experimentalmente.

O modelo proposto ajustou-se adequadamente aos dados experimentais. Os maiores desvios encontrados foram observados para valores de $\mathrm{pH}$ mais baixos.

Nota-se no gráfico acima que as curvas S para a extração de cobalto não são coincidentes para as diferentes concentrações iniciais $(0,01 \mathrm{M}$ e $0,005 \mathrm{M})$. Essa divergência pode ser atribuída às inerentes imprecisões experimentais e/ou ao fato de o Ksx da reação estar sendo afetado pela concentração do metal. O modelo ajustado à curva do cobalto $0,01 \mathrm{M}$ se ajustou melhor aos dados experimentais (função erro de 0,74 contra 1,46 apresentado pela curva do cobalto 0,005M) e, por esse motivo, para as considerações seguintes serão consideradas somente as determinações relativas ao experimento do cobalto $0,01 \mathrm{M}$. 


\subsubsection{Determinação do valor de $K s x$ (dados experimentais)}

Utilizando os valores de $A_{1}$ determinados pelo modelo, para cada um dos metais, e seguindo o mesmo método apresentado no item 5.1.3:

Tabela 5.8 - Determinação do parâmetro Ksx para os metais em estudo (a partir dos daos experimentais)

\begin{tabular}{ccc}
\hline Metal & $A_{1}$ & $K s x$ \\
\hline Cobalto & $-9,5868$ & $2,2618.10^{\wedge}-8$ \\
Magnésio & $-10,931$ & $1,0240.10^{\wedge}-9$ \\
Manganês & $-8,4098$ & $8,4098.10^{\wedge}-7$ \\
\hline
\end{tabular}

\subsubsection{Proposta de modelo para taxa de extração considerando solução multicomponente (concorrência dos metais)}

Até aqui, os modelos ajustados foram obtidos para soluções contendo apenas um metal extraível e ainda, com excesso estequiométrico considerável do agente extratante em relação ao metal extraído. Contudo, o processo de extração é, como regra, um processo em que mais de um metal é extraído concomitantemente e, por conta das exigências econômicas, o agente extratante é carregado muito próximo do seu limite. Essas duas modificações podem causar divergências substanciais entre 0 processo de extração real é o processo idealizado (modelo). O modelo a seguir tem a proposta de reduzir essa distância, buscando gerar um prognóstico mais assertivo para os processos industriais.

A proposta consiste em acoplar ao mecanismo de reação, um fator relativo ao balanço de massa do sistema. Isto é, para cada situação imposta ao sistema reacional, será considerado o consumo do agente extratante, estequiometricamente aos íons metálicos extraídos. Para cada metal, o parâmetro Ksx será então dado por:

$$
K_{s x}^{M e}=\frac{\left[H^{+}\right]_{a q}^{2} \cdot\left[R_{2} M e\right]_{o r g}}{\left[M e^{+2}\right]_{a q} \cdot[R H]_{o r g}^{2}}
$$


Em que a concentração do agente extratante no meio orgânico será:

$$
[R H]_{\text {org }}=[R H]_{\text {org }}^{0}-2 \cdot \sum\left[R_{2} M e_{i}\right]_{\text {org }}
$$

O índice 0 , refere-se ao estado inicial da solução. O símbolo Me foi utilizado para representar um metal bivalente genérico.

Resolvendo simultaneamente as equações resultantes do modelo acima para os íons dos metais de interesse $\left(\mathrm{Co}^{2+}, \mathrm{Mg}^{2+}\right.$ e $\left.\mathrm{Mn}^{2+}\right)$ e, utilizando os valores de $\mathrm{Ksx}$ determinados na Tabela 5.8, e comparando-se graficamente com os resultados do modelo anterior (sem o termo do balanço de massa), obtém-se:

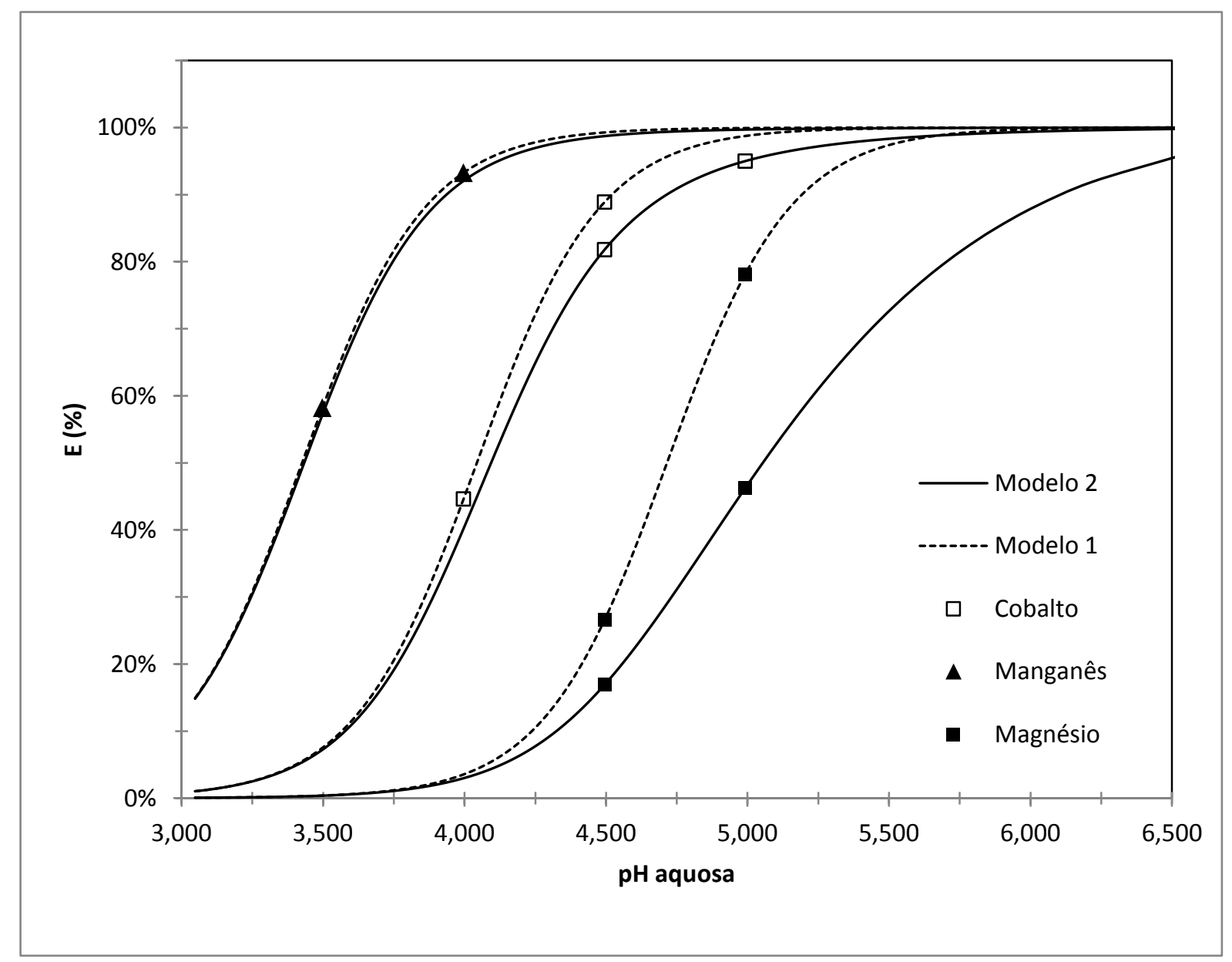

Figura 5.10 - Gráfico do modelo proposto para a taxa de extração $E(\%)$ para os metais estudados. Linhas contínuas representam o modelo considerando o balanço de massa. Linhas pontilhadas representam o modelo que não considera o balanço de massa. 
Vale ressaltar, novamente, que o parâmetro Ksx utilizado para determinar o modelo multicomponente foi determinado individualmente para cada metal através de experimentos em condições monocomponentes. A premissa considerada para isso é a de que a constante de equilíbrio para os metais permanece invariável para condições multicomponentes, desde que respeitadas as condições de temperatura. Essa consideração é fundamental para o desenvolvimento do modelo, aparentemente é razoável, mas será validada quando compararmos os resultados do modelo multicomponente com resultados experimentais nas mesmas condições.

Na simulação realizada, consideraram-se os seguintes parâmetros (típicos de uma operação comercial): Temperatura $=63^{\circ} \mathrm{C}, \quad\left[\mathrm{Co}^{2+}\right] \quad$ inicial $=0,0424 \mathrm{M}, \quad\left[\mathrm{Mg}^{2+}\right]$ inicial $=0,143 \mathrm{M},\left[\mathrm{Mn}^{2+}\right]$ inicial $=0,011 \mathrm{M}$, solução extratante $0,6 \mathrm{M}$ de Cyanex em Exxol, $\mathrm{O} / \mathrm{A}=1 / 1$. (Condições de processo fornecidas pela Votorantim Metais)

Nota-se importantes reduções na taxa de extração para os três íons metálicos

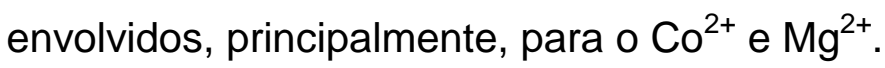

Para o caso específico do íon de cobalto, esse efeito é especialmente significativo, uma vez que a redução da taxa de extração pode inviabilizar a qualidade e pureza do produto final.

Comparando-se os resultados encontrados para o íon cobalto: 


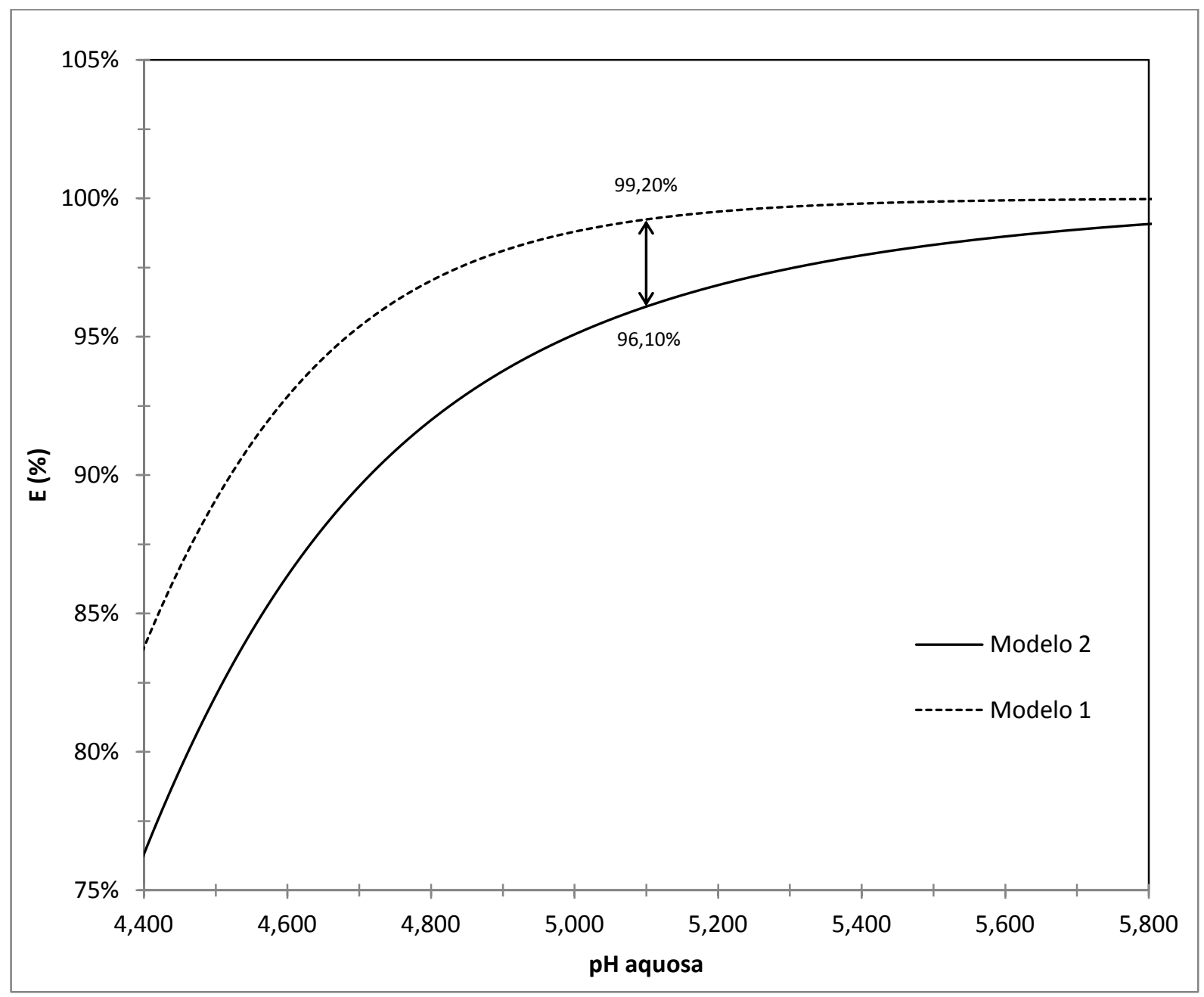

Figura 5.11 - Gráfico do modelo proposto para a taxa de extração $\mathrm{E}(\%)$ para os íons de cobalto. Linha contínua representa o modelo considerando o balanço de massa. Linha pontilhada representa o modelo que não considera o balanço de massa.

Nota-se que para o pH da solução aquosa anteriormente considerado ótimo, 5,1, se atingia um percentual de $99,2 \%$ de extração no modelo anterior. Para o novo modelo, em que se leva em consideração a presença dos outros íons (concorrentes) e o consumo do agente extratante, para pH de equilíbrio 5,1, a taxa de extração é de 96,1\% (Diferença indicada pela seta no gráfico). A taxa alcançada leva a fatores de separação $\mathrm{Ni} / \mathrm{Co}$ inferiores a 500 , no caso de se utilizar $\left[\mathrm{Ni}^{2+}\right]$ em $80 \mathrm{~g} / \mathrm{l}$, o que inviabiliza a produção comercial do níquel (conforme exposto na introdução deste texto). 
Este efeito está de acordo com o observado por (Soderstrom et al, 2010). No entanto, os autores atribuem essa diferença a alterações no equilíbrio da reação devido possíveis trocas iônicas entre metais, efeitos de diluição e alterações na estequiometria entre ligantes / metais. Enquanto que a diferença observada nos experimentos realizados neste trabalho, é explicada somente pelo acoplamento dos termos relativos do equilíbrio químico ao balanço de massa da reação.

Por fim, para verificar a aproximação do modelo proposto aos resultados reais, a curva foi comparada com dados experimentais obtidos nas mesmas condições de simulação:

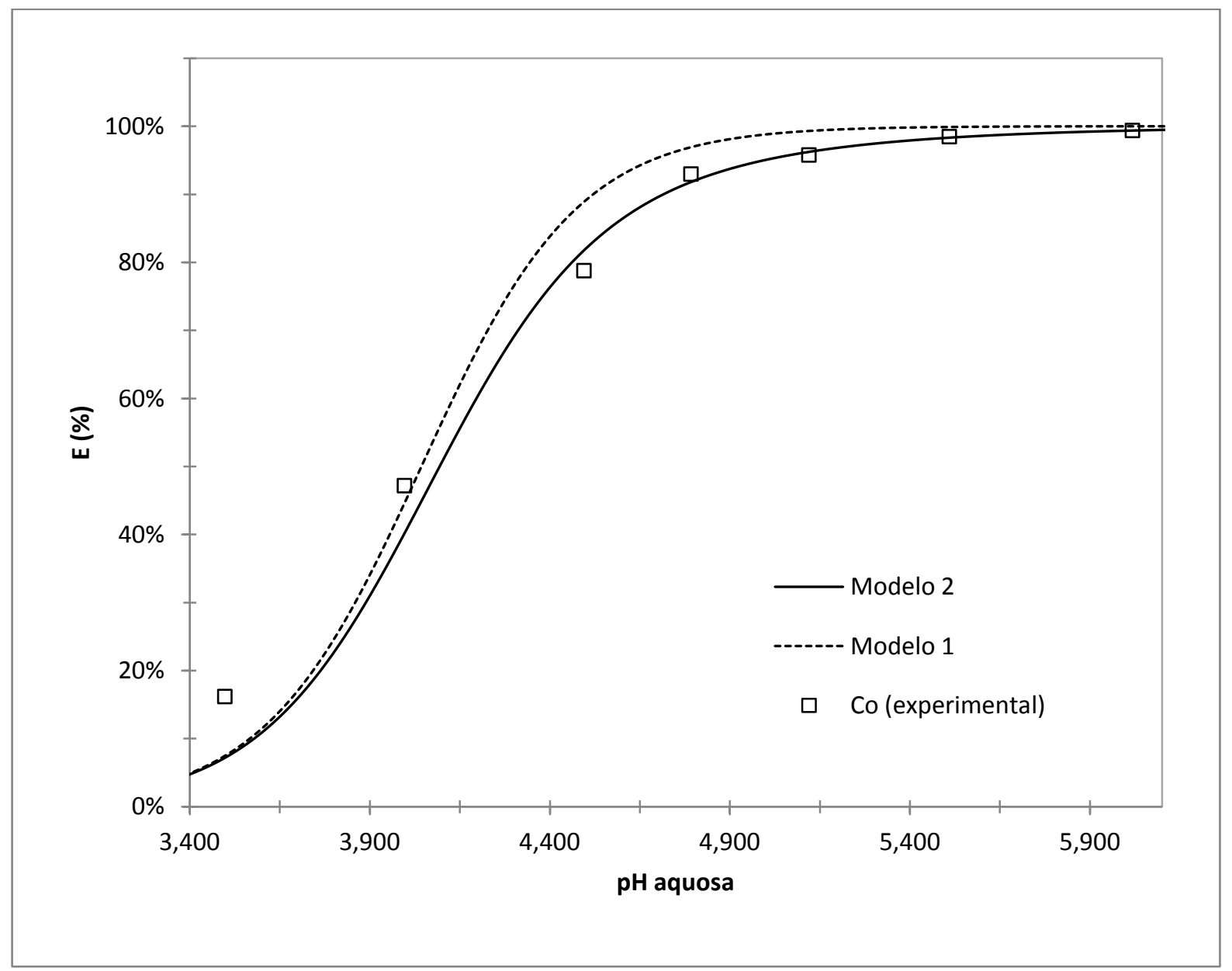

Figura 5.12 - Gráfico do modelo proposto para a taxa de extração $E(\%)$ para os íons de cobalto. Linha contínua representa o modelo considerando o balanço de massa multicomponente. Pontos ( $\square$ ) representam dados experimentais obtidos nas mesmas condições da simulação do modelo 
Pela observação do gráfico acima, é possível afirmar que o modelo proposto para a extração dos metais pelo ácido fosfínico, considerando os termos do balanço de massa e o consumo estequiométrico do agente extratante (modelo 2) se ajusta melhor aos valores experimentais nas mesmas condições do que o modelo que não considera o balanço (modelo 1). Estes resultados demonstram ainda, não ser necessário, para o caso dos metais e condições envolvidas, outros ajustes como a inclusão dos coeficientes de atividades, como sugerido na literatura. 


\section{CONCLUSÕES}

O modelo inicialmente proposto para o comportamento do equilíbrio líquido-líquido do processo de extração de íons metálicos (foram estudados os íons: $\mathrm{Co}^{2+}, \mathrm{Ni}^{2+}$, $\mathrm{Mg}^{2+}$ e $\mathrm{Mn}^{2+}$ ) mostrou um bom ajuste aos dados experimentais. Neste trabalho, investigou-se a dependência da taxa de extração dos íons em relação ao pH da solução aquosa. Outras variáveis como: temperatura, concentração do agente extratante e razão volumétrica $(\mathrm{O} / \mathrm{A})$ foram mantidas constantes.

A consideração, portanto, da concorrência de outros íons e o consumo proporcional do agente extratante (não considerados no primeiro modelo), é fundamental para o dimensionamento da unidade fabril e a qualidade dos produtos finais.

O segundo modelo proposto, no entanto, mostrou ser possível a utilização de modelos matemáticos que levem estes fatores em consideração, aproximando-se consideravelmente dos valores reais, e deste modo permitindo simulações mais assertivas em relação a diferentes cenários de processo.

Este segundo modelo acoplou ao mecanismo de reação, um fator relativo ao balanço de massa do sistema. Isto é, para cada situação imposta ao sistema reacional, foi considerado o consumo do agente extratante, estequiometricamente aos íons metálicos extraídos, e utilizando-se das constantes de equilíbrio previamente determinadas, as equações resultantes foram resolvidas simultaneamente.

A situação simulada, contudo, mostrou ser inviável alcançar fatores de separação $\mathrm{Ni} / \mathrm{Co}$ acima de 1000 conforme a necessidade de processo. Assim, faz-se necessário um ajuste nos parâmetros das soluções alimentadas, podendo ser (mas não somente) uma redução da concentração dos metais na solução aquosa alimentada, aumento da concentração do agente extratante na fase aquosa ou ainda, um incremento na relação volumétrica entre fases orgânica e aquosa $(\mathrm{O} / \mathrm{A})$.

A otimização do processo é uma excelente oportunidade para organização de trabalhos futuros e, pode, entre outras coisas, levar em consideração as variáveis citadas, além de simular outros cenários de alimentação de matéria prima, dimensionamento da unidade de extração, concentração dos íons envolvidos e o equilíbrio da extração em estágios contra-corrente. 


\section{REFERÊNCIAS}

Ashbrook, A., Lucas, B., \& Ritcey, G. (1975). Development of a Solvent Extraction Process for the Separation of Cobalt from nickel. Annual AIME Meeting. San Francisco: CIM Bull.

Baird, M. H., Hanson, C., \& Lo, T. C. (1991). Handbook of solvent extraction. Malabar, Florida: Krieger Publishing Company.

Bess, T., \& Schulz, W. (1984). Science and Technolgy of Tributyl Phosphate. USA: Pub. CRC Press.

Bourget, C., Sodestrom, M., Jakovljevic, B., \& Morrison, J. (03 de 11 de 2011). Optimization of the design parameters of a Cyanex 272 circuit for recovery of nickel and cobalt. Solvent Extraction and lon Exchange , pp. 823-836.

Burkin, A. (1987). Critical reports in applied chemistry (Vol. 17). John Wiley \& Sons.

Clemente, D. d., Dewar, B. I., \& Hill, J. (1980). Paper presented. CIM 10th Annual Hydrometallurgical Meeting. Edmonton, Canadá.

Coulaloglou, C., Gal-Or, B., Klinzing, G. E., Tavlarides, L. L., \& Zeitlin, M. A. (1970). Bubble and Drop Phenomena. Industrial \& Engineering Chemistry , 62, 6-27.

Cytec Industries Inc. (2008). Cyanex 272 Data Sheet. Acesso em 01 de 07 de 2012, disponível em Cytec: http://www.cytec.com

Ferreira, W. M. (2002). Modelagem e simulação do processo de extração seletiva de cobalto e níquel por solução orgânica através da aplicação de técnicas de redes neurais. Dissertação (mestrado) - Universidade Estadual de Campinas . Campinas, SP, Brasil.

Flett, D. S. (2004). Cobalt nickel separation in hidrometallurgy: a review. Chemistry for Sustainable Development, 12, pp. 81-91.

Flett, D. S. (1987). Critical reports in applied chemistry (Vol. 17). John Wiley \& Sons.

Flett, D. S. (1967). Solvent Extraction Chemistry. Amsterdam: Ed. Dyrrsen and Rydberg. 
Grinstead, R., \& Tsang, A. (1983). Solvent Extraction. Solvent Extraction Conference, (p. 230). Denver.

Hubli, R. C., Vikas, K., S., M., N., S. J., \& Suri, A. K. (2012). Evaluation of noctyl(phenyl) phosphinic acid (OPPA) as an extractant for separation of cobalt (II) and nickel (II) from sulphate solutions. Separation and Purification Technology , 89, pp. 66-70.

Kislik, V. S. (2012). Solvent Extraction: Classical e Novel Approaches. Amsterdan: Elsevier.

Koretsky, M. (2007). Termodinâmica para Engenharia Química. Rio de Janeiro: LTC.

Olivier, M. C. (2011). Developing a solvent extraction process for the separation of cobalt and iron from nickel sulfate solutions. Master Degree Dissertation. Matieland, África do Sul: Stellenbosch University.

Rickelton, W., \& Nucciarone, D. (1997). Hidrometallurgy and refining of nickel and cobalt (Vol. I). Metallurgical Society.

Ritcey, G. M. (2006). Solvent Extraction: Principles and applications to process metallurgy VI (2ª edição revisada ed.). Ottawa: A.W. Ashbrook.

Swain, B., \& Otu, E. O. (2011). Competitive extraction of lanthanides by solvent extraction using Cyanex 272: Analysis, classification and mechanism. Separation and Purification Technology , 83, pp. 82-90.

Tsakiridis, P., \& Agatzini, S. (2004). Hydrometallurgy , 72, pp. 269-278. 


\section{ANEXO A - CARACTERÍSTICAS FÍSICO-QUÍMICAS DO ÁCIDO DIALQUIL FOSFÍNICO (CYANEX 272)}

$\begin{array}{ll}\text { Aparência } & \text { Líquido translúcido } \\ \text { Massa molecular } & 290 \mathrm{~g} / \mathrm{mol} \\ \text { Densidade específica a } 24^{\circ} \mathrm{C} & 0.92 \\ \text { Viscosidade, Brookfield a } 25^{\circ} \mathrm{C} & 142 \mathrm{cP} \\ \text { Viscosidade, Brookfield a } 50^{\circ} \mathrm{C} & 37 \mathrm{cP} \\ \text { Solubilidade em água destilada a pH } 2.6 & 16 \mu \mathrm{g} / \mathrm{ml} \\ \text { Solubilidade em água destilada a pH } 3.7 & 38 \mu \mathrm{g} / \mathrm{mL} \\ \text { Ponto de ebulição } & \\ \text { Ponto de fusão } & \left(-32^{\circ} \mathrm{C}\right) \\ \text { Flash Point } & >108^{\circ} \mathrm{C} \\ \text { Calor específico a } 52^{\circ} \mathrm{C} & 0.48 \mathrm{cal} / \mathrm{gm} /{ }^{\circ} \mathrm{C} \\ \text { Condutividade térmica } & 2.7 \times 10-4 \mathrm{cal} / \mathrm{cm} / \mathrm{sec} /{ }^{\circ} \mathrm{C}\end{array}$

Estrutura química:

Ácido bis(2,4,4 trimetil-pentil) fosfínico

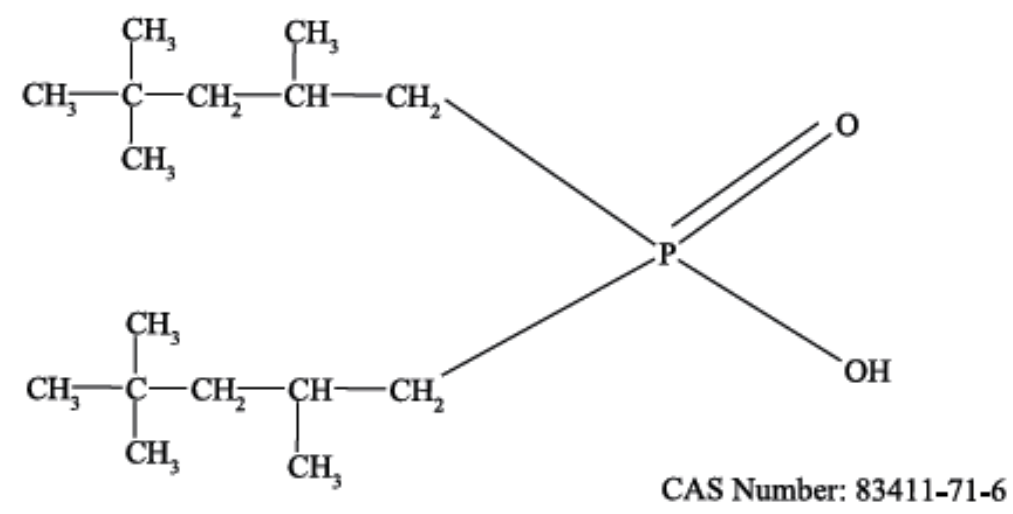

Fonte: (Cytec, 2008) 